$$
\begin{gathered}
\text { Universidade de Brasília } \\
\text { CET - Centro de Excelência em Turismo }
\end{gathered}
$$

Pós-graduação Lato Sensu

Curso de Especialização em Formação de Professores e

Pesquisadores em Turismo e Hospitalidade

\title{
"A TRANSIÇÃO DA ECONOMIA DE BENS PARA A INDÚSTRIA DO TURISMO NO JAPÃO NAS DÉCADAS DE 1970, 1980 E 1990"
}

VALTO CARDOSO DA SILVA 


\section{Universidade de Brasília \\ CET - Centro de Excelência em Turismo}

Pós-graduação Lato Sensu

Curso de Especialização em Formação de Professores e

Pesquisadores em Turismo e Hospitalidade

\section{"A TRANSIÇÃO DA ECONOMIA DE BENS PARA A INDÚSTRIA DO TURISMO NO JAPÃO NAS DÉCADAS DE 1970, 1980 E 1990"}

\section{VALTO CARDOSO DA SILVA}

\footnotetext{
Nome, Titulação

Professor Coordenador
}

Lytton L. Guimarães, Ph.D. Professor Orientador
Nome, Titulação Professor Examinador

"Trabalho apresentado em cumprimento às exigências acadêmicas parciais do curso de pós-graduação lato sensu em Especialização em Formação de Professores e Pesquisadores em Turismo e Hospitalidade para a obtenção do grau de Especialista"

Brasília - DF

Fevereiro/ 2006 
SILVA, Valto C.

A transição da economia de bens para a indústria do turismo no Japão nas décadas de 1970, 1980 e 1990/

Valto Cardoso da Silva

Monografia - Curso de Especialização em Formação de Professores e Pesquisadores em Turismo e Hospitalidade.

Brasília - DF, fevereiro de 2006.

Área de Concentração: Turismo e Hospitalidade

Orientador: Lytton Leite Guimarães

1. stratégia 2. Responsabilidade Social 3. Meio Ambiente 
Dedico a minha filha Viktoria, pequena princesa, que embora esteja do outro lado do mundo nunca deixará meu coração e sempre será o motivo de minhas realizações. 
Agradeço especialmente ao Prof. Dr. Lytton $L$. Guimarães pela acuidade em orientar voluntariamente a realização deste trabalho, pelas sugestões e observações para o êxito desta monografia e pelo estímulo para que possa continuar nessa jornada acadêmica. Também agradeço ao Francisco Denísio pelo auxílio na coleta de informações relevantes. 


\section{RESUMO}

Nos últimos tempos, o crescimento e a renovação de atividades produtivas impulsionadas pelo desenvolvimento tecnológico têm sido responsáveis pelo aumento do número de pessoas que viajam e pelo incremento da infra-estrutura turística. Segundo a Organização Mundial do Turismo (OMT, 2001), o turismo internacional mostrou um crescimento sustentável a uma taxa média anual de 6,8 \%, passando de 25 milhões de chegadas, em 1950, para 697,8 milhões em 2000, resistindo a condições políticas e econômicas adversas, e se tornando uma das maiores indústrias do mundo, com um faturamento de U\$ 477,9 bilhões. De acordo com dados divulgados pela Empresa Brasileira de Turismo EMBRATUR, a Conta Turismo do Brasil totalizou, em 2000, uma receita de US\$ 4.227.606 (gastos de turistas estrangeiros no Brasil), enquanto que a despesa somou US\$ 3.893.000 (gastos de turistas brasileiros no exterior), o que gerou um saldo positivo de US\$ 334.606. Diante da realidade do consumo de produtos turísticos e do progresso do turismo de massa, o presente trabalho tem por finalidade verificar a hipótese de que o turismo recente é parte de uma combinação de fatores sociais, econômicos, técnicos, culturais e políticos. No contexto da transição da economia de bens para a expansão do turismo no mundo, privilegiamos a relação entre demanda e oferta de infra-estrutura turística no Japão, nas décadas de 1970, 1980 e 1990. 


\section{SUMÁRIO}

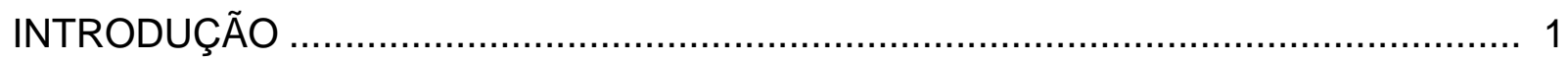

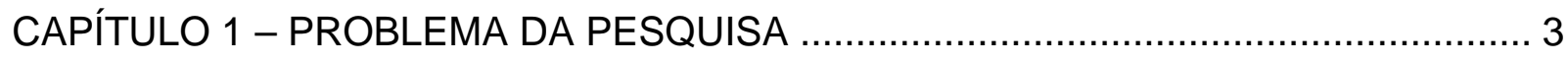

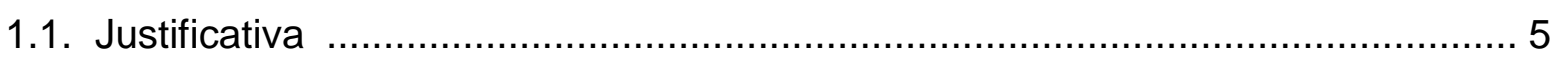

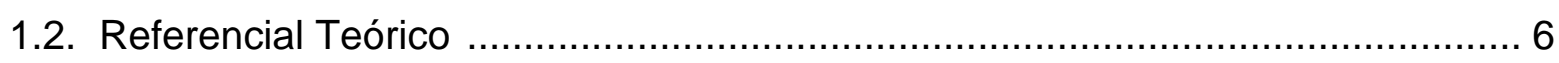

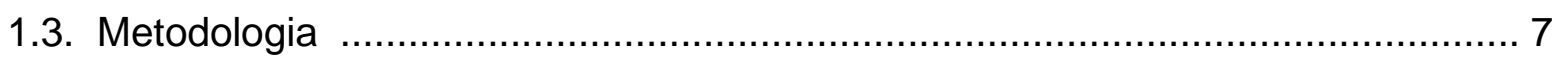

CAPÍTULO 2 - O CRESCIMENTO E A RENOVAÇÃO DA ATIVIDADE TURÍSTICA:

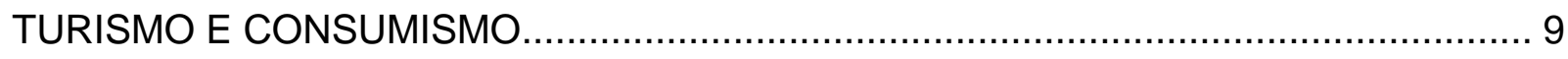

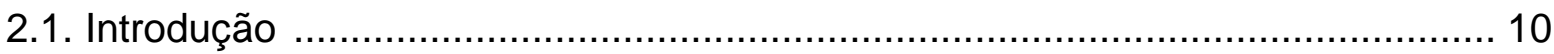

2.2 A Existência e o Acesso ao Atrativo Turístico............................................ 13

2.3. Intercâmbio Cultural e o Intercâmbio Econômico.......................................... 18

CAPÍTULO 3 - SISTEMAS DE TRANSPORTE E COMUNICAÇÃO NO JAPÃO........ 26

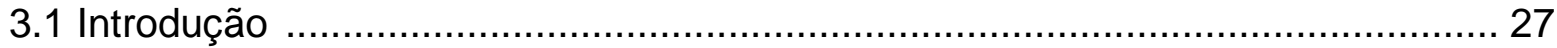

3.2. A Transição, o turismo e os Sistemas de Transportes no Japão ..................... 31

3.3. O Problema da Linguagem ............................................................. 37

CAPÍTULO 4 - ANÁLISE DOS DADOS ............................................................ 46

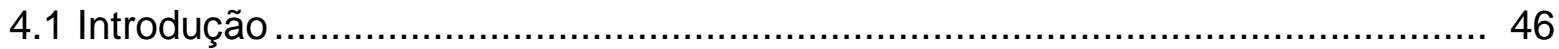

4.2 Crises e Mudanças Intensas e Abrangentes........................................... 46

4.3 Mediação e adequação da fala ......................................................... 52

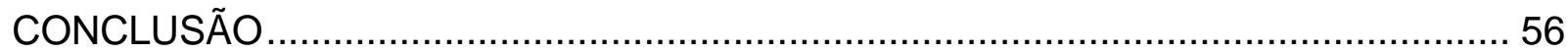

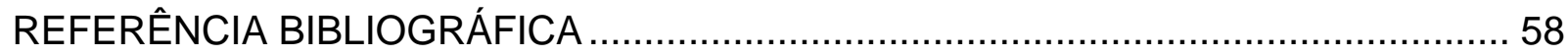

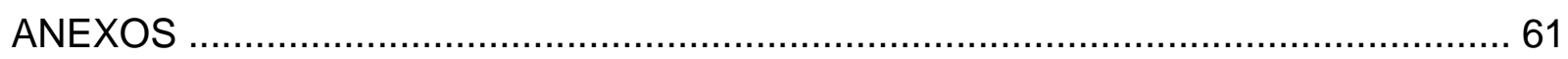




\section{INTRODUÇÃO}

Pelo menos até aqui, a relação modernização tecnológica versus desenvolvimento econômico tem mostrado a evolução no tempo, no que tange à disponibilidade de serviços ou técnicas disponíveis para vencer os obstáculos da distância entre povos.

Deslocar-se de um lugar a outro, dentre outras coisas, é uma condição para a satisfação de necessidades individuais ou coletivas.

Talvez tomando por base a sociedade japonesa, pode-se interpretar a sua história a partir da diminuição de distâncias, em cujo ponto se enumeram os elementos ou serviços utilizados para o cumprimento de propósitos, roteiros e destinos, combinando a disponibilidade de serviços facilitadores, serviços incentivadores e espaço ou território.

A concepção atual do Turismo recente tem vigência no século $X X$, quando se combinam uma série de fatores sociais, econômicos, técnicos, culturais e políticos.

A problematização, da qual resultou este trabalho, no curso de especialização em turismo da Universidade de Brasília, foi motivada pelos índices gerais do consumo de bens e serviços imposto pela sociedade global.

Antes de tudo, sem querer antecipar conclusões do presente trabalho, quando é referida a transição da economia de bens para a indústria do turismo no Japão, nas décadas de 70, 80 e 90 do século passado, pensa-se, direta ou indiretamente, num complexo de contribuições que possibilitaram a aproximação de mundos distintos e pessoas muito distantes.

O trabalho se baseia nos dados empíricos, conceituais e estatísticos, coletados na revista Tourism in Japan, analisados de acordo com a metodologia do trabalho científico orientada para o tema da atividade turística nacional do Japão.

Esta monografia, tomando por base a infra-estrutura turística consolidada no Japão,na questão da linguagem e, em particular, do problema da competência lingüística, enfoca a estrutura técnica e a institucionalização de guias-intérpretes na 
mediação entre anfitriões e visitantes estrangeiros, alargando a discussão do turismo para as relações entre varáveis nem sempre contempladas.

Para simplificar a compreensão do referido estudo, o trabalho, entre a mudança contemporânea da sociedade global e a expansão da produção e prestação de serviços, foi dividido entre duas grandes partes. A primeira parte compreende o capítulo 1, que disserta sobre a pesquisa, e a segunda, os capítulos 2, 3 e 4.

No capítulo 2, faz-se uma digressão discorrendo sobre o fenômeno trans-cultural do turismo, na sociedade global. O capítulo 3 contém um panorama social, político e econômico da atividade turística no Japão em particular.

Sem desconsiderar as limitações de espaço e tempo, alguns dados levantados, conceituais e estatísticos, são analisados no capítulo 4. 


\section{CAPÍTULO 1 - PROBLEMA DA PESQUISA}

Para participar do processo em que o turismo representa a própria transição da economia de bens para a indústria dos serviços, importa não apenas modernizar, produzir e competir. A atividade turística impõe a governos e sociedade a encontrarem os meios para o desenvolvimento econômico sustentável.

Nesse contexto, é de fundamental importância incorporar o ser humano que vive na região hospedeira e que participa diretamente da recepção e do atendimento ao visitante no planejamento e na execução dos programas turísticos; valorizar a mão-deobra local e universalizar a consciência acerca do papel representado, por cada um, nesse processo competitivo.

Na última década, dividindo espaço com a teoria econômica, tem surgido, com mais destaque, a preocupação com os efeitos negativos de um turismo de massas, principalmente sobre as comunidades mais frágeis, menos desenvolvidas. Nesse sentido, o enfoque da atividade turística passou a reconhecer a ameaça com a destruição do meio-ambiente, a segregação dos nativos, a exclusão dos autóctones de todo o processo de planejamento e, a longo prazo, um amplo confisco sobre a população local.

Há indicativos que mostram que quanto menor for o desenvolvimento da região receptora, maior será a intensidade dos efeitos negativos socioculturais resultantes do fluxo turístico sobre a população local. Para ilustrar como isso ocorre, no contexto da transição da economia de bens para a expansão do turismo no mundo, é privilegiada a relação entre demanda e oferta de infra-estrutura turística no Japão, nas décadas de 1970, 1980 e 1990.

Nesses termos, este trabalho tem por finalidade retratar o crescimento e a renovação da atividade turística japonesa a partir da mudança contemporânea e do capital globalizado, isto é, do significado do turismo de massa como determinante num contexto global de relações internacionais.

Seguindo a idéia de que o turismo hoje é um evento capaz de tornar os países como destino atraente para o capital globalizado, nestas páginas, o enfoque dessa 
atividade se afasta assim de muitas abordagens já desenvolvidas, no confronto de estudos que omitem ou conscientemente suspendem o conjunto de variáveis que converte o ramo turístico numa cadeia produtiva de bens e serviços.

Especificamente, o trabalho se propõe a mostrar que a transição da economia de bens para a indústria de serviços e, em particular, do turismo é parte de uma transformação na qual se identificam o regional e o global, em que valores tradicionais e a modernidade expressa na alta tecnologia, particularmente, no Japão, refletem a mudança contemporânea.

Pretende-se ainda mostrar que as raízes dessa mudança estão alicerçadas na história dos países ou regiões turísticas e são estruturadas por significados estruturantes, em larga medida, dos comportamentos atuais.

Dada a possibilidade de se observar na infra-estrutura turística e na institucionalização dos guias-intérpretes para visitantes estrangeiros a busca por uma harmonia entre os interesses dos turistas e o comportamento da população local, as medidas técnicas e os recursos humanos incorporados à atividade turística japonesa serão vistas na lógica da conscientização e do controle do desenvolvimento econômica daquele país.

Este trabalho pretende alcançar os seguintes objetivos:

1. retratar a cultura de turismo consolidada no Japão, discorrendo sobre a relação entre demanda e oferta de infra-estrutura turística nacional nas décadas de 1970, 1980 e 1990;

2. analisar a atividade turística como evento que caracteriza o sistema pósindustrial;

3. apresentar o desenvolvimento do Japão na transição da economia de bens para a indústria do turismo;

4. permitir certo confronto entre a organização turística japonesa e o desenvolvimento do turismo no Brasil. 


\subsection{Justificativa}

A despeito do desenvolvimento apressado e irresponsável de atividades turísticas, não é somente a preservação da diversidade cultural que preocupa. No alargamento dos horizontes social, político e econômico da mudança, o próprio meioambiente, as paisagens naturais e o patrimônio artístico-cultural também podem ser objeto de degradação, quando inexistem conscientização e controle.

Em países desenvolvidos, representados pela economia japonesa, os fatos apontam para um cruzamento jamais visto do desenvolvimento econômico, propugnado pela globalização dos mercados, com o progresso tecnológico, refletido na evolução dos sistemas de transporte e comunicação.

Por isso, a escolha desta pesquisa se baseou em alguns pontos fundamentais, a saber: (I) em tempos de globalização, o turismo vem alcançando enormes índices de crescimento em todo o mundo, por isso ele se converteu numa força econômica das mais importantes do mundo atual. Nele ocorrem fenômenos de consumo, originam-se rendas, criam-se mercados nos quais a oferta e a procura se encontram; (II) a redução da jornada de trabalho aponta para uma grande oportunidade de crescimento para o turismo e para as regiões que não tiveram muitas possibilidades de crescimento durante o domínio da sociedade do trabalho, em contraposição à indústria dos serviços.

Tendo tido a experiência de intercâmbio cultural no Japão, evento ocorrido durante o curso de graduação em Letras na Universidade de Brasília, com habilitação em japonês, o presente autor reconheceu a necessidade de se voltar para a questão do fluxo de pessoas naquele país, privilegiando a relação turismo e consumismo no mundo globalizado. Para o autor, o fenômeno em que valores tradicionais e a modernidade expressa na alta tecnologia se completam. Este fato leva a uma tentativa de compreender e interpretar as seguintes indagações: Como se dá a conversão da industrialização para a pós-industrialização? Quem são os visitantes turistas que entram e saem do Japão?

Os produtos da indústria turística perfazem um conjunto de diversos elementos de consumo que incluem lugares de interesses, serviços (transporte, guias, intérpretes, 
alojamento, comida, recreação), meio ambiente, cultura e hospitalidade. Além disso, um dos motivos de alteração violenta nas relações de emprego e renda é o avanço da tecnologia.

De fato, atualmente, passa-se por uma reestruturação profunda das práticas produtivas modernas. Apesar disso, tomando por base o problema econômico, sabe-se que muitas práticas produtivas tradicionais ainda estão em curso.

Essas considerações prévias, que antecedem ao principal objeto no momento, pretendem ser muito mais do que uma antecipação da relação entre demanda e oferta de infra-estrutura turística no Japão, nas décadas de 1970, 1980 e 1990: as transformações deflagradas no interior do sistema pós-industrial e no fenômeno da globalização permitem por si só destacar a atividade turística no fluxo de capital e na capacidade competitiva dos países.

\subsection{Referencial Teórico}

Atualmente, vive-se na era da informação, em um mundo onde aprende-se, gradativamente, a encurtar as distâncias e a redimensionar o tempo. O cotidiano das pessoas está, continuamente, sendo transformado com a incorporação de produtos que permitem a comunicação com qualquer parte do planeta.

Hoje, os acontecimentos locais sofrem a influência de algo vivenciado por povos do outro lado do mundo. O tempo livre dessas comunidades, assim como o seu dia-adia, é bombardeado pelos meios de comunicação que vendem sonhos de consumo. Através desses estímulos, a viagem televisiva vai tomando forma por meio de fantasias que fazem crescer a expectativa quanto à realização do desejo de conhecer outros lugares, outras gentes, outras culturas.

As alterações no ritmo de vida dos seres humanos vão, cada vez mais, impulsionando-os a adotar, como alternativa de lazer, a viagem. E a sociedade capitalista, responsável pela intensificação do ritmo de trabalho, logo transforma essa opção de uso do tempo livre em mercadoria. 
O início da movimentação turística coincide com o desenvolvimento da sociedade industrial, mas o surgimento de um "turismo de massas" ou um "turismo moderno" foi observado a partir da década de cinqüenta e mais recentemente, com o aceleramento do processo de globalização. O turismo, de modo geral, tem apresentado um desenvolvimento surpreendente, movendo milhões de dólares a cada ano.

Além da estabilidade política de muitos países, do crescimento econômico (com a formação das classes médias), da melhoria das condições de vida de uma parcela da população (com a redução das horas de trabalho), dos avanços tecnológicos (com o transporte mais rápido e a comunicação facilitada), o acesso a manifestações culturais e à educação para um maior número de pessoas despertou o interesse em conhecer outras manifestações culturais, outros lugares.

A importância econômica da atividade turística tem superado expectativas da sociedade global. Não há como fugir a essa realidade. Então, tem-se notado a tentativa de adequação a essas novas mudanças por parte de todas as sociedades, pois o turismo é agora um fenômeno mundial.

O aspecto da comunicação entre as pessoas que viajam ou, até mesmo, o contato direto com a natureza e a cultura da região visitada figura como fator não menos preocupante das viagens turísticas, que permitem ao homem contemporâneo interagir com outras realidades.

\subsection{Metodologia}

Realizou-se uma pesquisa bibliográfica em livros e revistas especializadas. Através disso, foi levantada e revisada a literatura existente para a elaboração conceitual e definição de marcos teóricos que foram repassados ao longo destas páginas.

Por se tratar de um assunto pouco explorado, fez-se necessário uma importação de dados e conceitos do turismo no Japão, a fim de extrair informações que possibilitassem delimitar a investigação e adotar uma metodologia adequada de 
análise. Foram utilizadas as edições de 1960-70, 1980 e 1991 da Revista Tourism in Japan, publicação japonesa subordinada respectivamente à Japan National Tourist Organization (JNTO) e ao Ministério dos Transportes do Japão.

Constatando-se a existência do fluxo doméstico e do turismo internacional, o passo seguinte foi vislumbrar um percurso que permitisse delinear a conversão da era industrial para a fase dos serviços, que compreende o próprio turismo. Para delimitar a preocupação deste estudo, resolveu-se aprofundar aquele pressuposto de que o turismo é uma atividade que atualmente combina fatores sociais, econômicos, técnicos, culturais e políticos.

Em linhas gerais, entrecruzando a pesquisa teórica com conclusões que podem ser analisadas academicamente, o caminho utilizado para estudar o turismo na relação entre demanda e oferta de infra-estrutura turística no Japão, nas décadas de 1970, 1980 e 1990, foi construído a partir de dados apresentados que possibilitam os especialistas a alcançarem estatísticas satisfatórias em relação aos efeitos do turismo sobre a economia japonesa. 


\section{CAPÍTULO 2 - O CRESCIMENTO E A RENOVAÇÃO DA ATIVIDADE TURÍSTICA: TURISMO E CONSUMISMO}

Ao se perguntar: "A propósito da atividade complexa, plural, integrada, interdependente, sistêmica que é o turismo, quem são os agentes que trabalham com os aspectos culturais, sociais e ambientais que comportam a atividade turística? Qual a importância de uma infra-estrutura direcionada e orientada para a mediação entre a oferta e o acesso aos atrativos turísticos?", está-se de fato questionando essa "máquina" de geração de emprego, renda e divisas que é o turismo. Situar estas perguntas no contexto do capital globalizado implica também na possibilidade de analisar questões ilustrativas e que determinam o paradigma atual.

Nesses termos, a relação do sistema pós-industrial (da descentração e reestruturação do poder e do fluxo das comunicações) com o padrão globalizado da hospitalidade imposta pela sociedade global, sem sombra de dúvida, implica numa concepção atual do turismo e que reflete a flexibilidade e a versatilidade cultural do momento.

Por isso, é importante e necessário trazer para essa discussão pelo menos duas considerações que têm motivado medidas que reduzem a sociedade global à conquista de mercados. Considerações essas que representam questões fundamentais para o desenvolvimento deste trabalho: primeiro, o fato de que, num passado não muito distante, a era pós-industrial foi vislumbrada como um tempo de avanço tecnológico, que traria às pessoas mais conforto e tempo livre; e segundo, que após a II Guerra Mundial, com a emergência de uma nova economia baseada na revolução digital, as pessoas passam a conviver com a existência de sistemas de negócios ágeis e enxutos.

Para que se possa entender os motivos deste estudo, em paralelo com as transformações impostas pela revolução tecnológica e pela economia de negócios ágeis e enxutos, ou, quem sabe, pela pós-industrialização, será feita uma pequena digressão, percebendo o turismo como uma extensão do materialismo da vida moderna e parte integrante da cultura de consumo. 


\subsection{Introdução}

Em razão do caráter dinâmico da atividade turística, somado à necessidade de compensar desajustes de outros setores da economia, surgem novas ações que visam explorar cada vez mais as potencialidades do turismo. Dentre as quais vem despontando, de forma promissora e com incontestável benefício para o setor, habilidades dos recursos humanos e capacidades gerenciais que estão diretamente voltadas para roteiros internacionais ou mesmo para o turismo doméstico.

De início, no que concerne à interpretação turismo entre, é importante antecipar que, neste trabalho, privilegia-se a questão da duplicidade teoria e prática, que envolvem o assunto. Paralelo à relação transporte e turismo, é introduzido o tema da competência comunicativa no Japão, chamando atenção para fatores lingüísticos, sociais e culturais que, compreendendo funções elementares para o convívio e para as relações humanas, desempenham um papel fundamental na interação entre o anfitrião e o visitante turista.

No seu esforço de realizar uma análise acadêmica da atuação da lingüística concreta $^{1}$ e da competência comunicativa no turismo, o presente autor procurou retratar o bilingüismo de imigrantes. Para ele, no que concerne à metodologia deste estudo, a mudança de código lingüístico vivida por imigrantes pode ser comparada ao processo interativo entre visitantes turistas e guias-intérpretes de um país ou região visitada, que representa e reproduz os problemas relativos a dois ou mais falantes de línguas diferentes.

A conversão de signos e a mudança de código, também extensivas à relação entre a competência comunicativa e o fenômeno turístico, aparecem neste estudo como uma conjugação útil para se começar a dar visibilidade de fato a questões menos imediatas, no que tange à infra-estrutura turística.

De qualquer modo, sem a pretensão de querer antecipar conclusões a respeito desse tema, na intercomunicabilidade de variáveis que estão direta ou indiretamente

\footnotetext{
${ }^{1}$ Lingüística concreta diz respeito ao movimento dialético entre criação e repetição incluindo todas as variações que o falante pode acrescentar às inúmeras estruturações lingüísticas já formuladas e aceitas socialmente.
} 
relacionadas com o turismo, a especialização tende a privilegiar a absorção apenas de elementos que se ajustam a certos interesses, contrapondo a teoria à prática.

Por esse particular, em paralelo com interações entre a globalização da economia, o desenvolvimento dos meios de transporte e o desejo crescente das pessoas para o turismo, dá-se a passagem da industrialização para o crescimento da indústria de serviços.

Enfim, nos últimos tempos, o crescimento e a renovação de atividades produtivas impulsionadas pelo desenvolvimento tecnológico são responsáveis pelo aumento no número de pessoas que viajam e pelo incremento da infra-estrutura turística. Segundo a Organização Mundial do Turismo (OMT, 2001), o turismo internacional mostrou um crescimento sustentável a uma taxa média anual de 6,8 \%, passando de 25 milhões de chegadas, em 1950, para 697,8 milhões em 2000, resistindo a condições políticas e econômicas adversas, e se tornando uma das maiores indústrias do mundo, com um faturamento de U\$ 477,9 bilhões.

Também de acordo com dados divulgados pela Empresa Brasileira de Turismo EMBRATUR, a Conta Turismo do Brasil totalizou, em 2000, uma receita de US\$ 4.227.606 (gastos de turistas estrangeiros no Brasil), enquanto que a despesa somou US\$ 3.893.000 (gastos de turistas brasileiros no exterior), o que gerou um saldo positivo de US\$334.606.

Diante disso e tomando como base causas e efeitos que explicam a preocupação da sociedade global por segmentos específicos de mercado, este trabalho não pretende ser uma análise depurada da relação dos meios de transportes com o turismo no Japão. Ele está organizado de forma a oferecer uma compreensão geral de algumas variáveis pelas quais pode-se analisar fatores que influenciam o turismo.

A prestação de serviços de transporte, de certa forma, é um processo complexo que demanda muitas habilidades dos recursos humanos e capacidades gerenciais. Nesses termos, o desenvolvimento dos sistemas de transporte, e isto é o que de fato motiva a discorrer sobre a relação entre demanda e oferta de infra-estrutura turística no Japão, tem vários impactos sociais, culturais, econômicos e físicos, diretos e indiretos, no atendimento da atividade turística. 
Por isso, para entender a complexidade e as relações que coexistem entre infraestrutura (meios de transporte) e turismo, é apresentado um estudo de caso que pode ajudar a sintetizar os diferentes fatores e processos que afetam a organização, operação e o gerenciamento de atividades associadas às viagens turísticas.

Para Luzia Neide Coriolano, a idéia de viajar, vem penetrando de tal forma na mente do homem moderno que, cada vez mais, é vista como uma conquista, um direito, uma possibilidade, um consumo. Segundo a autora, pode-se afirmar que a viagem é hoje um dos grandes consumos criados no contexto da sociedade através dos meios de propagação coletiva, sobretudo os meios de comunicação de massa eletrônicos (CORIOLANO, 1998).

Discorrendo não sobre a idéia de viajar propriamente dita, Mike Robinson discute efeitos das viagens e do turismo. Para ele, o conflito entre turista e anfitrião talvez seja o mais evidente nos impactos sociais, culturais, econômicos e físicos, diretos e indiretos.

Ele nasce em parte de uma divergência radical de objetivo: o primeiro entrega-se a uma atividade de prazer, o segundo trabalha. O turista chega com muitas expectativas; os anfitriões, com muita freqüência, não têm a menor idéia do que devem esperar dele (ROBINSON, 1999:22).

Eis aqui uma perspectiva que, ultrapassando o encantamento e a diminuição de distâncias entre as pessoas, relaciona a evolução dos sistemas de transporte e comunicação, que compreende os avanços técnicos e o aumento da oferta de serviços, com os efeitos negativos do turismo, com os quais turistas e não-turistas são obrigados a conviver.

Por outro lado, o sucesso da interação entre o visitante turista e os locais de destino, a necessidade de instaurar mecanismos que garantam que o desenvolvimento do turismo seja sustentado (ou seja, que seus benefícios sociais e ecológicos a longo prazo tenham prioridade sobre seus lucros a curto prazo), e o papel crucial das autoridades locais na concepção dos projetos turísticos, bem como a avaliação de seu 
interesse pela população, são alguns dos temas que entrecruzam a demanda e a oferta do turismo.

Vislumbrados como indicativos de conforto e tempo livre para as pessoas, num futuro muito próximo, o avanço tecnológico, a revolução da informática e os modernos aparelhos eletrônicos (o que não representa uma questão não menos importante para o tema do turismo) passaram a relacionar a era pós-industrial com a drástica redução, em escala global, do número de postos de trabalho nos mais diversos setores da economia.

Enfim, no desemprego estrutural ${ }^{2}$, tendência do atual período pós-industrial, tem levado muitos a buscarem respostas para a questão, desde a análise dos significados e representação do desemprego às implicações que trazem o aumento do tempo livre, na transição do mundo do trabalho para o mundo do ócio.

Diante de tal transição, o turismo passou a ser objeto de interesse de algumas tendências e a ser considerado parte do caminho para uma sociedade centrada no atual processo de viagens e na experiência turística.

Nesses termos, ao lado de hipótese de que a viagem é hoje um grande produto de consumo e que a cultura é um insumo turístico importante, segue uma problematização da produção e da prestação de serviços turísticos, tomando por base a relação entre demanda e oferta de infra-estrutura turística no Japão, na transição da economia de bens para a indústria do turismo nas décadas de 1970, 1980 e 1990.

\subsection{A Existência e o Acesso ao Atrativo Turístico}

Características como facilidade, segurança e rapidez nos meios de transporte, novas tecnologias, têm facilitado o deslocamento crescente de pessoas em vários destinos. Nessa perspectiva, para confirmar a projeção da indústria do turismo, é

\footnotetext{
${ }^{2} \mathrm{O}$ termo desemprego estrutural se refere às mudanças que ocorrem no mundo do trabalho, no aumento sistemático do desemprego.
} 
apresentado abaixo alguns indicadores básicos para se situar a evolução do setor, com a colaboração de novas tecnologias aplicadas ao transporte turístico.

TABELA 1.1 - Quanto os Países Gastaram com o Turismo

\begin{tabular}{|c|c|c|c|c|}
\hline \multirow[t]{2}{*}{ Ordem } & \multicolumn{2}{|c|}{$\begin{array}{c}\text { Turismo } \\
\text { Internacional } \\
\text { Gastos (Bilhões/US\$) }\end{array}$} & \multirow{2}{*}{$\begin{array}{c}\% \\
\text { Mudança } \\
\text { 2001/2000 }\end{array}$} & \multirow[t]{2}{*}{$\begin{array}{c}\text { Fatia do Mercado } \\
2001\end{array}$} \\
\hline & 2000 & 2001 & & \\
\hline 1. Estados Unidos & 64.5 & 58.9 & -8.7 & 12.7 \\
\hline 2. Alemanha & 47.6 & 46.2 & -3.0 & 10.0 \\
\hline 3. Reino Unido & 36.3 & 36.5 & 0.6 & 7.9 \\
\hline 4. Japão & 31.9 & 26.5 & -16.8 & 5.7 \\
\hline 5. França & 17.8 & 17.7 & -0.2 & 3.8 \\
\hline 6. Itália & 15.7 & 14.2 & -9.4 & 3.1 \\
\hline 7. China & 13.1 & - & - & - \\
\hline 8. Hong Kong & 12.5 & 12.5 & -0.1 & 2.7 \\
\hline 9. Países Baixos & 12.2 & 12.0 & -1.7 & 2.6 \\
\hline 10. Canadá & 12.1 & 11.6 & -4.3 & 2.5 \\
\hline 11. Bélgica & 9.4 & 9.8 & 3.6 & 2.1 \\
\hline 12. Áustria & 8.5 & 8.9 & 4.4 & 1.9 \\
\hline 13. R. da Koréia & 6.2 & 6.9 & 11.5 & 1.5 \\
\hline 14. Suécia & 8.0 & 6.8 & -15.1 & 1.5 \\
\hline 15. Suíça & 6.2 & 6.6 & 5.2 & 1.4 \\
\hline
\end{tabular}

Fonte: TODD, Graham. Viagem e Turismo na Atualidade. In: Viagem e Hospitalidade. Barueri, São Paulo: Manole, 2003, p. 11. 
TABELA 1.2 - Países que mais Enviam Turistas

\begin{tabular}{|c|c|c|c|c|}
\hline \multirow{4}{*}{ Ordem } & \multirow{3}{*}{\multicolumn{2}{|c|}{$\begin{array}{c}\text { Turismo Internacional } \\
\text { Receitas } \\
\text { (US\$ bilhões) }\end{array}$}} & \multirow{4}{*}{$\begin{array}{c}\text { Variação } \\
\text { (\%) } \\
\text { 2000/2001 }\end{array}$} & \multirow{4}{*}{$\begin{array}{c}\text { Quota } \\
\text { Mercado (\%) } \\
2001\end{array}$} \\
\hline & & & & \\
\hline & & & & \\
\hline & 2000 & 2001 & & \\
\hline 1. Estados Unidos & 64.5 & 58.9 & -8.7 & 12.7 \\
\hline 2. Alemanha & 47.8 & 45.8 & -3.0 & 9.9 \\
\hline 3. Reino Unido & 38.3 & 36.9 & 1.5 & 8.0 \\
\hline 4. Japão & 31.9 & - & - & - \\
\hline 5. França & 17.7 & 17.5 & -1.4 & 3.8 \\
\hline 6. Itália & 15.7 & 14.2 & -9.2 & 3.1 \\
\hline 7. China & 13.1 & - & - & - \\
\hline 8. Países Baixos & 12.2 & - & - & - \\
\hline 9. Canadá & 12.1 & - & _ & - \\
\hline 10. Bélgica & 10.2 & - & - & - \\
\hline 11. Áustria & 9.3 & 9.7 & 4.0 & 2.2 \\
\hline 12. R. da Koréia & 6.2 & 6.9 & 11.5 & 1.5 \\
\hline 13. Suécia & 6.0 & 6.8 & -15.1 & 1.5 \\
\hline 14. Suíca & 6.2 & 8.6 & 5.2 & 1.4 \\
\hline 15. Taiwan & 5.4 & - & - & - \\
\hline
\end{tabular}

Fonte: Op. cit., p. 10. 
TABELA 1.3 - Os doze primeiros mercados internacionais de viagens emissivas (1997)

\begin{tabular}{|c|c|c|c|c|}
\hline $\begin{array}{l}\text { Ranking } \\
1990\end{array}$ & 1997 & País & $\begin{array}{l}\text { Gastos - } 1997 \\
\text { (US\$ milhões) }\end{array}$ & $\begin{array}{l}\text { \% compartilhada } \\
\text { do total do mundo }\end{array}$ \\
\hline 1 & 1 & Estados Unidos & 51.220 & 13,5 \\
\hline 2 & 2 & Alemanha & 46.200 & 12,2 \\
\hline 3 & 3 & Japão & 33.041 & 8,7 \\
\hline 4 & 4 & Reino Unido & 27.710 & 7,3 \\
\hline 5 & 5 & Itália & 16.631 & 4,4 \\
\hline 6 & 6 & França & 16.576 & 4,4 \\
\hline 7 & 7 & Canadá & 11.268 & 3,0 \\
\hline 9 & 8 & Holanda & 10.232 & 2,7 \\
\hline 40 & 9 & China & 10.166 & 2,7 \\
\hline 8 & 10 & Áustria & 10.124 & 2,7 \\
\hline- & 11 & Rússia & 10.113 & 2,7 \\
\hline 13 & 12 & Bélgica & 8.275 & 2,2 \\
\hline Subtotal & & & 251.556 & 66,5 \\
\hline Todos os outros & & & 128.201 & 33,5 \\
\hline Total mundial & & & 379.757 & 100,0 \\
\hline
\end{tabular}

Fonte: Op. cit., p. 9. 
Perante esses números, além da observação de que o turismo é o ramo atual da produção e da prestação de serviços em ascensão, a tabela 1.1 mostra quanto determinados países gastaram com o turismo, entre 2000 e 2002, segundo a Organização Mundial do Turismo (OMT). Tais dados refletem o desenvolvimento de uma organização interna e protagonizada por local de destino dos turistas, com meios humanos e materiais que permitam orientação e ordenamento dessa atividade.

A existência e o acesso ao atrativo turístico referem-se a duas pré-condições das quais depende o êxito do setor. Segundo dados da OMT, de 2001, nos últimos 50 anos o turismo internacional mostrou um crescimento sustentável a uma taxa média anual de 6,8 \%, passando de 25 milhões de chegadas, em 1950, para 697,8 milhões em 2000, resistindo a condições políticas e econômicas adversas, e se tornando uma das maiores indústrias do mundo, com um faturamento de $\cup \$ 477,9$ bilhões.

O setor de turismo, nos seus diversos segmentos, apresenta-se como uma alternativa para o desenvolvimento futuro das sociedades. No entanto, conforme os impactos culturais, sociais e ambientais que comportam a atividade, este desenvolvimento não é simples, precisa de trabalho de planejamento que visem a maximização dos impactos positivos que o turismo pode gerar e minimização dos negativos.

Com a preocupação de ajustar a preservação da identidade cultural e social dos espaços visitados pelos turistas à geração de emprego, renda e divisas, o conceito de desenvolvimento turístico passou a sofrer um intenso processo de revisão, mais ou menos crítico, mais ou menos cauteloso conforme o ambiente intelectual e profissional. Percebeu-se, sobretudo, uma dimensão fortemente política e ética circunscrita à atividade econômica, o que tinha sido ignorado de certa forma pela teoria econômica anterior, ou, simplesmente, pela economia de bens.

O que produzir, como produzir, para quem produzir, tornam-se questões-chave que devem fazer parte de todo processo de gestação de projetos econômicos. Aqui passa-se de um ambiente gerido pelo conceito estreito de "desenvolvimento turístico" para iniciar a discussão do conceito mais amplo de "desenvolvimento sustentável" (CAPORALI, 1995). 
Apesar de existir um grande número de interpretações do que realmente é o desenvolvimento sustentável, a OMT define o termo como um modelo de desenvolvimento econômico que é elaborado levando em conta os seguintes objetivos:

a) Melhorar a qualidade de vida da comunidade receptora;

b) Prover uma experiência de alta qualidade para o visitante; e

c) Manter a qualidade ambiental tanto para a comunidade quanto para o visitante.

Neste estudo, privilegia-se de certa forma a prestação de serviços para o visitante cujo padrão é de alta qualidade e, voltando ao tema da mudança, pela qual a demanda e a oferta referentes ao turismo forçam uma relação plena de condições e perspectivas para o turista. Contudo, sabe-se que a experiência de alta qualidade não pode nem deve resultar do efeito mecânico de uma mudança de mentalidade, visando a sustentabilidade do setor em questão.

Por isso, no cumprimento dos objetivos propostos para este estudo, e concordando com o pressuposto de que o turismo recente combina uma série de fatores sociais, econômicos, técnicos, culturais e políticos, é destacado, aqui, dois eventos que motivam e determinam o turismo: o desenvolvimento de uma infraestrutura física, refletida nas melhorias dos sistemas de transporte e comunicação, e a promoção dos recursos humanos, ou seja, a qualificação de profissionais que atuam diretamente com os visitantes turistas.

\subsection{Intercâmbio Cultural e o Intercâmbio Econômico}

Segundo Suzana Gastal (2001), é preciso que a cultura deixe de ser apresentada, exclusivamente, do ponto de vista do lugar, do sedentário, como algo acabado, como produto a ser assimilado/consumido:

Cultura é um insumo turístico importante, mas é aquela cultura viva, praticada pela comunidade em seu cotidiano. Não é um espetáculo, que inicia quando o ônibus dos visitantes chega, mas uma atividade que a comunidade exerce rotineiramente. Quando os 
visitantes chegarem, eles serão bem vindos e convidados a juntos dançar, cantar, saborear o pão, aplaudir o artista (GASTAL, 2001:129).

O desempenho da atividade turística, na aproximação de mundos tão distintos como o europeu e o asiático, ilustra claramente como a oferta e a procura pelo turismo podem invadir todos os limites da sociedade. O que motiva esse tipo de consideração é de certa forma o investimento em iniciativas que determinam o crescimento econômico e o progresso social, na busca de novos segmentos que dinamizam o capital e a sociedade global..

Por outro lado, a promoção do turismo internacional segue as regras da oferta e da demanda dentro de uma economia de mercado, e tanto as sociedades que geram como as que recebem turistas estão sujeitas aos ditames deste sistema.

Na sociedade capitalista moderna, o tempo e o espaço concedidos ao trabalho e ao ócio (lazer) podem ser determinados com precisão matemática e as atividades turísticas passam a ser vistas como uma forma de preencher o tempo "livre" de empregados. Aqueles que têm o poder político e econômico para dinamizar a atividade produtiva podem modelar valores e gostos desse público alvo do turismo, os trabalhadores em férias.

O turismo de massa pode ser interpretado por suas relações de poder e, por isso, suscetível à padronização e homogeneização. Em todas as experiências de massas, inclusive nos aspectos ideológicos e de consumo, essa relação de poder ameaça o pensamento, a escolha e a ação individuais.

No desenvolvimento do turismo na Ásia, o atual processo de entrada e saída de visitantes reflete um estágio particular de transformação da sociedade do trabalho.

Por isso, diante do consumismo generalizado de bens e serviços que eliminam fronteira entre Ocidente e Oriente, pode-se lembrar da crítica ao turismo identificado com a comercialização de sociedades inteiras, sua cultura, seu ambiente e sua identidade. Esse fenômeno, baseado na alienação do pensamento, da escolha e da ação de indivíduos e culturas, estaria eclipsando as sociedades asiáticas e mudando o comportamento das pessoas. 
A despeito da globalização de interesse e oportunidades, a experiência tem sugerido que as atividades de passatempo dos asiáticos não diferem muito daquelas do Ocidente.

Lembrando do Japão cuja modernização tecnológica foi impulsionada por forças que estimularam as exportações japonesas das décadas de 70 e 80 e que depois passaram a ser responsáveis pelo turismo emissivo, não parece difícil relacionar as medidas de atração do capital globalizado com as conseqüências decorrentes da abertura local, regional ou nacional para a competição externa.

Contudo, ainda enfocando a questão problemática que atinge o desenvolvimento do turismo e a crítica da sociedade de consumo, ressalta-se aqui as considerações de Antônio Pereira Oliveira, em Turismo e Desenvolvimento: planejamento e organização (2000).

Segundo o autor acima, deve-se reconhecer e atentar para o fato de que a atividade turística é capaz de produzir efeitos negativos, como promover um crescimento desordenado decorrente do excesso da oferta de serviços, aumentar o preço dos produtos e serviços locais, destruir o patrimônio material e imaterial, dentre outras (OLIVEIRA, 2000).

Nessa perspectiva, o processo de comercialização e homogeneização, produto da redução das distâncias e da aproximação entre mundos, junto com a circulação massiva de novas idéias, imagens e informação, tomariam o espaço das tradições locais, das expressões culturais, dos valores familiares e comunitários.

Em linhas gerais, nesse processo particular de transformação da sociedade do trabalho, a economia tem sido orientado para uma evolução (quem sabe, revolução) ainda maior e, nesse sentido, tudo parece concorrer para um estágio no qual as pessoas já não fariam mais trabalhos pesados, não produziriam objetos em fábricas e oficinas mecânicas, não sujariam as mãos em linhas de montagem, nem suariam diante de altos-fornos.

Enfim, confrontando o tópico do acesso com o atrativo turístico na Ásia, os dados passíveis de generalização da indústria do turismo trazem à tona os limites do intercâmbio econômico e cultural, decorrentes dessa atividade. Nessas circunstancias, 
a relação entre variáveis diversas que dinamizam a economia e projetam o turismo produz pelo menos duas reações distintas e excludentes: a extensão do protecionismo empregado nas relações multilaterais aos impactos do turismo e a crítica da sociedade do consumo.

De acordo com o que já foi exposto antes, é muito difícil concluir se, no percurso da economia de bens para o setor de serviços no qual se está situando a atividade turística, os movimentos massivos de pessoas e a criação de novas oportunidades sociais e pessoais indicam uma superação do modelo de urbanização, industrialização e desenvolvimento científico e tecnológico.

Contudo, entrecruzando duas concepções, a da cultura como insumo turístico importante e aquela da cultura como bem de consumo, em Megatendências Ásia: oito megatendências asiáticas que estão transformando o mundo, de J. Naisbitt, o surgimento do turismo regional é uma das principais características da revolução consumista da Ásia.

De repente, segundo NAISBITT, os asiáticos puderam viajar, e, chegando a uma certa exposição via satélite, foram incitados à curiosidade sobre lugares longe e não tão distantes.

De certa forma, o objetivo principal do livro de J. Naisbitt é apresentar um esquema interpretativo da transformação que está atingindo a sociedade global e, nesse contexto, o turismo figura como uma dessas megatendências asiáticas que estão transformando o mundo.

Por isso, no sistema onde o poder e o fluxo das comunicações se reestruturam, seguindo as megatendências asiáticas, faz 10 anos que as cabines de classe executiva de aviões e as salas de recepção dos hotéis de cinco estrelas eram monopólio de executivos, trabalhadores de multinacionais na Ásia. Atualmente, os asiáticos que viajavam a negócio em classe econômica e se alojavam em hotéis de média categoria usam cada vez mais a classe executiva e os melhores hotéis. Desse modo uma nova geração de asiáticos de classe média que desejavam visitar amigos e familiares na região cria uma oportunidade extraordinária para os hotéis de preço médio (NAISBITT, 1998). 
Nesse contexto, John Naisbitt considera que o Japão possui uma importância relativa para a emergência da Ásia. E mais, para ele, o que acontecer na Ásia e no Oriente, em geral, irá influenciar o Ocidente e o resto do mundo. A Ásia vive a migração do modelo de especialização intensivo em mão-de-obra para outro, apoiado na tecnologia e no saber.

Por outro lado, acredita-se que um fator de maior relevância para o sucesso da Ásia diz respeito à numerosa emigração de asiáticos que, nos anos 60 e 70, procuraram o Ocidente e, depois que tiveram acesso a uma formação específica, hoje regressam à sua terra natal.

No seu livro anterior a 1998, Global Paradox, Naisbitt defendeu que, à medida que as economias são mais globais, maior é o poder das pequenas empresas. $O$ mundo gira demasiado depressa e as empresas demasiado hierarquizadas não conseguem competir. Têm de romper com o passado, porque o mercado global implica em inovação constante.

Aqui, aborda-se novamente um pensamento que diz que a concepção atual do turismo recente tem vigência no século $X X$, quando são combinados uma série de fatores sociais, econômicos, técnicos, culturais e políticos.

Enfim, na combinação e disponibilidade de serviços facilitadores, serviços incentivadores e espaço ou território, grandes infra-estruturas são criadas para satisfazer à indústria de consumo, para prestar serviço aos indivíduos, etc.

De certa forma, a literatura existente sobre o desenvolvimento do turismo não tem dedicado para esta matéria uma atenção que reflita de fato um tratamento particular da questão. Talvez isso seja porque o turismo de massa é um fenômeno recente que supera de fato as preocupações tradicionais da economia e por não ter a mesma representatividade para todas as cidades e/ou regiões, ou ainda, pelo fato de que freqüentemente o turismo é associado a lazer e descanso.

Também, não é difícil concordar que quando surgiu a ciência econômica, o turismo não tinha a atual transcendência, e o elemento humano da economia era menos relevante que hoje. Por isso, é justo que, na teoria e na prática, trate-se de 
encontrar formas mais adequadas para as categorias sociais, políticas e econômicas do turismo.

Relacionando os objetivos da atividade econômica com a necessidade do desenvolvimento do turismo sustentável, a indústria da prestação de serviços passara a articular varáveis até então isoladas nesse processo.

Por isso, a partir de uma visão conjunta entre diversas variáveis (indústria, turismo, desenvolvimento econômico e impactos sócio-culturais), destacar-se-á cada vez mais a necessidade de se manter uma relação solidária entre as variáveis envolvidas na atividade turística, sem tentar maximizar qualquer um delas, isoladamente.

Dentre as medidas de promoção desse setor, a qualificação de agentes mediadores diretos entre os visitantes turistas e o espaço hospedeiro seria aquela que certamente compreende o turismo como uma das forças transformadoras do mundo pós-industrial, que ajuda a redesenhar as estruturas mundiais, influenciado pela globalização, pelos novos negócios econômicos e por uma nova ordem internacional.

É, nessa perspectiva, que no conjunto do turismo, na estruturação e qualificação da recepção e da hospitalidade para o visitante estrangeiro, a promoção de habilidades dos recursos humanos demanda políticas públicas específicas voltadas para a manutenção e sustentabilidade do setor.

Portanto, o turismo, associado ao atual processo de entrada e saída de pessoas de um determinado lugar, tende a exigir medidas complementares à infra-estrutura nos pólos emissores de fluxos, nos espaços de deslocamentos e nos núcleos receptores de turistas, em meio à modernização e disseminação das comunicações e ao alargamento e barateamento das ofertas de transporte.

No capítulo a seguir, a pretexto dessas medidas complementares a serem acrescentadas à atividade turística, tratar-se-á de discorrer sobre a exigência de alta qualidade das relações turísticas ou por que o turismo não pode nem deve ser reduzido aos milagres da revolução científica e tecnológica dos últimos 50 anos, a pretexto do desenvolvimento econômico e do progresso social. 
Resumindo, a intensidade e a velocidade das mudanças do capital globalizado, que desafiam governos e sociedade a tomarem posicionamentos adequados para os novos momentos, de forma a continuar atendendo às expectativas de suas demandas, convertem-se nos problemas do desequilíbrio social e da própria sobrevivências de sociedades inteiras.

Nesses termos, os profissionais do turismo enfrentam permanentes desafios para a conseguir atrair sua clientela pela excelência dos serviços turísticos. A questão da hospitalidade reflete de forma decisiva no futuro dessa atividade. Os profissionais dessa área precisam estar devidamente capacitados de forma a atender, satisfatoriamente, aos desejos dos turistas, ou seja, ao consumo de produtos e serviços, em sintonia com a era do conhecimento e da informação.

A arte do bem servir e receber torna-se, portanto, uma condição essencial. Ao espírito hospitaleiro deve ser agregado um atendimento profissional, compondo um capital humano capacitado para atender a demanda. Nessa perspectiva, a evolução das comunicações, o alargamento e o barateamento das ofertas de transporte são fundamentais e não dispensam a complementaridade de outros agentes para o sucesso atividade turística.

Portanto, a partir do momento em que esforços sejam direcionados no sentido de se alcançar um treinamento voltado para a cultura da hospitalidade, investindo na capacitação contínua dos profissionais atuantes nos pólos emissores de fluxos, nos espaços de deslocamentos e nos núcleos receptores de turistas, o turismo irá deixar de figurar como uma atividade compensatória, que tem por fim corrigir prejuízos de outros setores.

Perante a oferta e a procura de acesso a núcleos receptores de turistas, governos (federal, estaduais e municipais) e sociedade destacam-se como responsáveis imediatos no que tange ao crescimento e à renovação da mão-de-obra turística.

Por certo, a despeito das potencialidades do turismo, esses mesmos responsáveis poderão prover a prestação de serviços turísticos de profissionais e 
especialistas, requisitando o contingente qualificado oriundo das escolas e dos centros universitários brasileiros para o mercado de trabalho, anualmente. 


\section{CAPÍTULO 3 - SISTEMAS DE TRANSPORTE E COMUNICAÇÃO NO JAPÃO}

A imensa indústria do turismo atual, segundo é conhecida, tem sido alimentada por vários fatores, dentre os quais é possível destacar: o crescimento real de renda e a expansão do transporte público, rápido, eficiente e muito acessível, juntamente com amplo acesso ao transporte privado.

Mais uma vez, é importante lembrar que, no caráter dinâmico das relações social, política e econômica contemporânea, entre transporte e turismo coexistem complexidade e relações onde segmentos turísticos diversos apontam para o consumo de bens e serviços também diversos.

A multiplicidade de motivações que está na origem das deslocações e as características peculiares das necessidades dos visitantes turistas não permitem delimitar claramente os contornos da oferta turística. Sabe-se, contudo, que o atual processo de viagem é uma parte integrante da experiência turística.

Por certo, é a partir dos dados entre o turismo receptivo e o turismo emissivo que se pode e deve-se analisar o fenômeno turístico no Japão.

O movimento de pessoas na superfície do planeta está ficando mais visível devido à globalização da economia, ao desenvolvimento de meios de transporte e ao desejo crescente das pessoas para o turismo. O século $X X I$ representará uma fase de muitas trocas no mundo todo, aperfeiçoando assim as relações sociais e o intercâmbio cultural iniciado noutras datas.

Para se ter uma idéia dessas mudanças, basta acrescentar que as viagens turísticas e o fluxo de passageiros têm a possibilidade de movimentar 54 trilhões de ienes na economia japonesa, fato que comporta uma oportunidade econômica particular, conseqüência do movimento nacional e transnacional de pessoas no planeta.

Nesse contexto, cabe entender por que os governos locais do Japão promovem o turismo articulando várias medidas para o setor, como também por que a discussão em torno do fluxo de pessoas na sociedade global projeta o crescimento e a renovação da atividade turística naquele país. 
Deixando de lado a evolução do turismo internacional e voltando para este tema, ressalta-se que o turismo depende da qualificação de recursos humanos ${ }^{3}$, bem como de medidas essenciais de infra-estrutura, refletidas nas melhorias dos sistemas de transporte e comunicação, passa-se a enfocar o Japão como expressão de uma cultura de turismo consolidada.

Para o presente autor, a qualificação e as medidas essenciais mencionadas aqui seriam indicativos dessa cultura. E mais, a análise do turismo no Japão, nas décadas de 70, 80 e 90 do século passado, recupera pelo menos dois pontos: o problema dos determinantes e motivadores do setor e a questão do turismo doméstico.

Neste capítulo, apresenta-se questões sobre alguns meios de transporte e sobre a cultura de turismo consolidada na sociedade japonesa, esta sob o esforço de ações conjuntas de uma economia que associa diretamente o desenvolvimento tecnológico à mediação dos recursos humanos.

\subsection{Introdução}

Para a compreensão desta parte do trabalho será utilizado o tema do turismo doméstico, na tentativa de introduzir uma análise dessa questão, a partir da experiência japonesa. Também, será enfocado o fluxo interno de consumidores japoneses no Japão e, por conseguinte, apresentado de forma breve algumas considerações sobre essa subdivisão da economia de bens e serviços turísticos.

A tabela 2.1 revela os números do fluxo doméstico de passageiros no Japão, relativos às décadas de 70,80 e 90 do século XX. Nos dados estão incluídos os tipos de transporte que de certa forma refletem a evolução da oferta de serviços rodoviários, aéreos, e ferroviários nesse país.

\footnotetext{
${ }^{3}$ Neste caso, fazemos referência para os profissionais que atuam diretamente junto ao visitante estrangeiro.
} 
TABELA 2.1 - Passageiros Domésticos Classificados por Meio de Transporte no Japão

- No de Passageiros (em Milhões) -

\begin{tabular}{ccccccccc}
\hline Década & Total & $\begin{array}{c}\text { Sistema } \\
\text { Público }\end{array}$ & Shinkansen & $\begin{array}{c}\text { Companhia } \\
\text { Privada }\end{array}$ & Ônibus & Carro & Aéreo & Marítimo \\
\hline 1970 & 40.606 & 6.534 & 85 & 9.850 & 11.812 & 12.221 & 15 & 174 \\
1980 & 51.720 & 6.825 & 126 & 11.180 & 9.903 & 23.612 & 40 & 160 \\
& $(12.0)$ & $(-3.2)$ & $(-19.7)$ & $(6.0)$ & $(-7.7)$ & $(33.5)$ & $(60.0)$ & $(-5.9)$ \\
\hline 1990 & 77.934 & 8.358 & 260 & 13.581 & 8.558 & 47.209 & 65 & 163 \\
& $(0.9)$ & $(4.7)$ & $(9.9)$ & $(2.6)$ & $(-0.2)$ & $(-0.1)$ & $(8.5)$ & $(1.5)$ \\
\hline
\end{tabular}

Fonte: Tourism in Japan, edição de 1993.

1. ( ) expressa o crescimento proporcional entre décadas (\%);

2. Os algarismos inteiros refletem os números de unidade de Shinkansen e de veículos aéreo e marítimo.

Ao examinar o turismo industrial no Japão relativo à década de 1960, pode-se observar que por esse tempo houve um número crescente de visitas estrangeiras que desejaram conhecer empresas industriais e fábricas para observar o alto nível do modelo industrial japonês.

Devido a essa tendência, o Ministério dos Transportes tomou a iniciativa de compilar um arquivo de empresas e fábricas nacionais em japonês, para a conveniência de visitas estrangeiras. Em 1965, com base numa pesquisa de âmbito nacional de empresas e fábricas principais, foi emitida pelo Ministério a primeira edição do arquivo de turismo industrial no Japão.

Além disso, a edição de 1969-1970 da revista Tourism in Japan mostrava que, em relação ao passado, a demanda pelas viagens no Japão, dentro e fora do país, dava sinais de aumento. Os fatores principais dessa tendência, dentre outros, são: o aumento de renda individual; o aumento de horas desocupadas devido à redução da jornada de trabalho; e o advento do sistema de férias de verão. 
TABELA 2.2 - Números das Convenções Internacionais por categorias (19801990)

\begin{tabular}{ccccccccccc}
\hline Categoria & $\begin{array}{c}\text { Política } \\
\text { Direito } \\
\text { Ano }\end{array}$ & $\begin{array}{c}\text { Ciência } \\
\text { Tecnologia } \\
\text { Economia }\end{array}$ & $\begin{array}{c}\text { Indústria } \\
\text { Medicina }\end{array}$ & $\begin{array}{c}\text { Arte } \\
\text { Cultura } \\
\text { Educação }\end{array}$ & $\begin{array}{c}\text { Transporte } \\
\text { Turismo }\end{array}$ & Social & Religião & Esporte & Outros & Total \\
1981 & 65 & 151 & 53 & 65 & 12 & 15 & 3 & 2 & 5 & 371 \\
1982 & 97 & 157 & 65 & 79 & 19 & 23 & 3 & 1 & 12 & 456 \\
1983 & 76 & 145 & 65 & 50 & 12 & 16 & 0 & 4 & 16 & 384 \\
1984 & 66 & 164 & 62 & 48 & 12 & 33 & 3 & 5 & 15 & 408 \\
1985 & 121 & 190 & 45 & 38 & 10 & 20 & 2 & 6 & 6 & 438 \\
1986 & 62 & 261 & 53 & 48 & 4 & 16 & 6 & 5 & 47 & 502 \\
1987 & 124 & 250 & 42 & 49 & 7 & 57 & 7 & 5 & 8 & 549 \\
1988 & 151 & 402 & 36 & 63 & 11 & 71 & 3 & 6 & 21 & 764 \\
1989 & 199 & 401 & 45 & 86 & 16 & 94 & 4 & 12 & 8 & 865 \\
\hline 1990 & 206 & 520 & 43 & 118 & 23 & 97 & 7 & 10 & 53 & 1077 \\
\hline
\end{tabular}

Fonte: Tourism in Japan, edições de 1980 e 1991.

De acordo com os números da tabela 2.2, o turismo está relacionado com viagens, porém nem todas as viagens são consideradas como turismo. Tal informação permite deduzir que a atividade turística atua indiretamente, gerando renda não só na indústria turística complementar, mas em quase todos os setores da sociedade. $O$ reflexo do turismo se faz sentir, dentre outros setores, na construção civil, na indústria alimentar, na produção de móveis e utensílios domésticos, nos serviços de profissionais liberais e no movimento bancário.

Nesses termos, quando se retoma a questão da multiplicidade de motivações que está na origem das deslocações e as características peculiares das necessidades dos visitantes turistas, talvez não reste dúvida quanto aos efeitos multiplicadores do turismo.

Além do mais, a partir de tais considerações é possível ter uma noção das potencialidades de uma cultura de turismo consolidada e que, conforme explicitam os 
fatos e dados estatísticos, começaria pelo fluxo interno de pessoas dos países receptores de turistas, passando depois para a atração do turismo internacional.

Portanto, a realidade proporciona o reconhecimento de que em países como a Alemanha, Japão, França já existe uma cultura de turismo consolidada, são povos que fazem do ato de viajar prioridade em suas vidas e ao viajar sabem como desfrutar ao máximo das diferenças e das particularidades do destino visitado.

Investimentos em educação para o lazer, mostrando através do turismo as belezas e as diferenças entre as regiões no interior de cada país, isso reflete em primeiro lugar a causa do desenvolvimento do turismo doméstico nos países desenvolvidos.

Apesar dos efeitos multiplicadores e das potencialidades do turismo, ainda hoje na maioria dos países, assim como no Brasil, a cultura das viagens turísticas não existe, sendo relativamente poucas as pessoas que podem viajar. No que tange ao caso brasileiro, ante a defesa do turismo como um dos principais fatores a serem abordados na educação para o lazer, para os negócios e para a cultura, convive-se com índices sociais negativos decorrentes de outros setores da economia.

Por outro lado, talvez por experiência própria, sabe-se que o desenvolvimento estritamente econômico pode ocorrer sem que, automática ou forçosamente (ou proporcionalmente) haja melhoria no quadro de distribuição de renda e consequentemente dos indicadores sociais.

Por isso mesmo, pela ausência de uma cultura de turismo consolidada e pelas diferenças entre países desenvolvidos e países em desenvolvimento, não se pode ignorar que a atividade turística é capaz de produzir efeitos negativos, contrariando a tese de que o turismo poderia compensar desequilíbrios econômicos locais.

Por fim, a relação dos eventos e das convenções internacionais com o mundo industrializado, bem como a preocupação com o problema da linguagem decorrente do turismo industrial do Japão, conforme já foi mencionado, levam-nos à conclusão de que o turismo depende do desenvolvimento econômico e social de sociedades abertas e livres, critérios inacessíveis a maioria dos países, segundo Graham Todd (2003): 
[...] Se medirmos o mundo com base nesses critérios, fica evidente que, hoje em dia, a maior parte não se sai bem. Tal comparação revela dois fatos importantes. Primeiro, a maioria da população mundial tem ainda que atingir o que, no mundo industrializado, considera-se como nível mínimo de abastecimento desses elementos. Segundo, como conseqüência, se todos aqueles considerados não privilegiados podem, de forma razoável, ter esperanças de acessar esses itens durante o próximo século, a capacidade para o crescimento da demanda, no turismo nacional e internacional, é, levando-se tudo em conta, ilimitada. (TODD, 2003:5)

\subsection{A Transição, o turismo e os Sistemas de Transportes no Japão}

No que tange à história e à sociedade japonesa, sabe-se que a crise decorrente da modernização econômica da Era Meiji (1868-1912) gera os principais "push factors" responsáveis primeiramente pelos significativos movimentos migratórios internos no Japão e depois pelas altas taxas de emigração para outras regiões do mundo. Dentre esses fatores destaca-se a implantação da indústria pesada, associada a medidas de modernização seletiva, com a substituição de práticas produtivas tradicionais.

Aqui, talvez, tenta-se ordenar e orientar a relação entre demanda e oferta de infra-estrutura turística no Japão, na transição da economia de bens para a indústria do turismo, para a pergunta: "Se e em que sentido, perante os problemas conjunturais relativos à modernização econômica da Era Meiji, os japoneses passaram a perceber no setor turístico um grande potencial para o desenvolvimento interno?".

Essa e outras perguntas, no declínio do papel de algumas atividades econômicas e das mudanças da sociedade global, poderiam responder por que o turismo do século $\mathrm{XX}$ em diante combina uma série de fatores sociais, econômicos, técnicos, culturais e políticos.

Primeiro, superando a possibilidade de se resumir o presente trabalho à pergunta acima, a relação do turismo com o desenvolvimento nacional japonês aponta mesmo para aquilo que motiva e propõe o turismo doméstico: uma infra-estrutura nacional de meios de transporte, telecomunicações e outras. 
Em segundo lugar, estão as pressões externas, decorrentes de mudanças globais e da competição internacional, que de certa forma determinam mais ainda a combinação de recursos e condições internas dos países globalizados.

A evolução da demanda turística do Japão, entre 1964 e1981, segundo Stephen J. Page (1999), pode ser atribuída a vários fatores:

- crescimento contínuo nos negócios internacionais e a geração de riquezas na economia japonesa;

- aumento do nível de vida da população, e capital disponível para gastar ou itens supérfluos, como viagens;

- liberação das restrições à moeda estrangeira em 1964;

- simplificação dos procedentes administrativos para obtenção de passaporte e visto;

- tecnologia aérea aperfeiçoada, que facilita acesso a destinações estrangeiras;

- desenvolvimento e marketing de pacotes de férias que reduzem os preços das viagens.

No cruzamento das políticas do governo com as viagens emissivas no Japão, Stephen lembra que, no tocante às viagens emissivas na sociedade japonesa, a ética do trabalho sempre militou contra as férias longas:

"A política do governo endossou as viagens emissivas e as encorajou positivamente, como forma de responder às críticas internacionais em relação ao superávit comercial acumulado." (PAGE, 1999:144)

Partindo do fato de que o Japão tem combinado o próprio turismo para solucionar problemas sociais e econômicos internos, tal referência faz lembrar Takafusa Nakamura e Bernard Grace (1985), segundo os quais, considerando a crescente interdependência entre as nações e o papel que dele se espera como 
segunda maior economia do mundo, o Japão tem tomado sucessivas medidas para a abertura do seu mercado aos produtos estrangeiros, para a promoção das importações e para evitar a exportação excessiva de produtos específicos.

Na perspectiva de NAKAMURA e GRACE (1985:99), as respostas daquele país às críticas internacionais do superávit japonês por si só geram novos horizontes e possibilidades, permitindo a combinação de fatores e a promoção do turismo.

Contudo, é nesse contexto que, sob os efeitos econômicos da atividade turística, o crescimento do setor terciário projeta a evolução japonesa, em meio as mudanças operadas nos meios comerciais.

A propósito, que mudanças seriam essas operadas nos meios comerciais, senão reações impostas ao enorme superávit comercial do Japão? A economia precisou ser reestruturada de modo a superar os desequilíbrios decorrentes do superávit comercial japonês, gerado através de sua balança de pagamentos.

Por sua vez, a reestruturação da indústria e a reforma do Estado protagonizada pelos japoneses nessa fase indicaram uma nova era da tecnologia, da indústria e do poder econômico local e global.

Resumindo, no Japão, após a década de 90, com as preocupações orientadas agora para a demanda interna, o que contrata fortemente com a economia das décadas de 70 e 80, voltada para a exportação, a realidade aponta para um novo rumo recorrentes dos indicadores da expansão das viagens emissivas, o que chama a atenção para uma transição entre o passado e o presente na sociedade japonesa.

Por outro extremo, a demanda turística japonesa seria afetada por sua oferta inadequada de infra-estrutura turística, o que de certa forma poderia ser justificado graças ao reconhecimento de que o Japão seria o representante completo da sociedade do trabalho.

É a partir desse contexto que, após ter incorporado as tendências da era pósindutrial, na história atual do Japão, as viagens internacionais e o transporte turístico crescem em paralelo com a indústria do turismo. 
Por isso, evocando ainda a combinação de fatores que passaram a projetar a atividade turística, destaca-se como fato curioso e também marcante para a evolução dos sistemas de transporte e comunicação do Japão a promoção das viagens turísticas, somada ao reforço do setor de serviços, em resposta à crescente pressão internacional para que o país reduzisse seu superávit comercial.

Na primeira metade do século XIX, os sistemas de transporte e de comunicação desencadearam as primeiras inovações com os primeiros barcos a vapor (Robert Fulton/1807) e locomotiva (Stephenson/1814), revestimentos de pedras nas estradas (McAdam/1819), telégrafos (Morse/1836). Daí as grandes mudanças que essas inovações promoveram ou mesmo promoveriam num futuro próximo. As distâncias entre pessoas, entre países, entre mercados se encurtariam. Os contatos mais regulares e freqüentes permitiriam uma maior aproximação de mundos tão distintos como o europeu e o asiático.

Neste contexto, é possível reconhecer que a tecnologia possibilitou a redução de custos e do tempo de deslocamento dos meios de transporte, por outro, viabilizou a interação, em tempo real, de regiões geograficamente distantes, sem necessidade de deslocamento físico.

Sem perder de vista ainda os problemas decorrentes da revolução tecnológica, sabe-se que, possibilitando aos países, às organizações e aos indivíduos um reconhecimento prévio dos destinos de viagem, o progresso também trouxe a possibilidade da discriminação de alguns lugares, excluídos dos roteiros de viagens. Assim, o fato de os meios de transporte estarem cada vez mais velozes, contribuiu para a integração entre países, regiões e continentes.

Após a II Guerra Mundial, a rede de transportes do Japão se desenvolveu em paralelo com o crescimento econômico do país, proporcionando o aumento da demanda gerada pelo crescimento global da sociedade. Entretanto, um traço marcante do sistema de transportes do Japão é sua alta dependência das estradas de ferro em comparação com outros países. Criadas como empresas públicas em 1949, as Ferrovias Nacionais Japonesas (FNJs) deram uma grande contribuição à reconstrução econômica do Japão nos anos do pós-guerra e ao período posterior de crescimento 
econômico rápido e, em 1964, ganharam uma reputação de liderança mundial em tecnologia ferroviária, em especial após terem lançado o primeiro sistema mundial de trânsito ferroviário de alta velocidade, o Shinkansen (às vezes, chamado de trem-bala).

Contudo, nos últimos anos tem havido sinais de uma mudança significativa do transporte ferroviário para o rodoviário e até aéreo e, num esforço para dinamizar as operações ferroviárias, em 1987, o governo privatizou as FNJs .

Nas maiores cidades, os sistemas de metrô são importantes meios de transporte. A rede de metrô de Tóquio tem uma extensão total de duzentos quilômetros. Os metrôs também operam em outras oito cidades, inclusive Osaka e Nagoya.

A extensão de estrada por quilômetro quadrado no Japão (três quilômetros) é boa se comparada com as cifras nos Estados Unidos (0,7 quilômetro) e na República Federal da Alemanha (dois quilômetros), que tem o sistema rodoviário mais avançado da Europa Ocidental.

Até o início da década de 1970, o Japão era uma das maiores nações marítimas do mundo. Nesse período muitas mudanças surgiram com a chegada do transporte aéreo de carga e pela competição crescente de parte das indústrias de transporte marítimo dos países em desenvolvimento. Tomando carona na economia baseada nos sistemas de negócios ágeis e enxutos, transporte aéreo japonês expandiu-se tanto em termos de oferta como de demanda. O aumento nos níveis de renda deu às pessoas oportunidades cada vez maiores de viajar. O transporte aéreo também passou a ser usado cada vez mais para o transporte doméstico.

Essa demanda pelo transporte aéreo vem aumentando a uma taxa muito alta o setor de negócios, posto que o tempo menor da viagem tem uma relação direta com o desempenho das relações comerciais e das atividades econômicas. Outro fator a favor das viagens aéreas domésticas tem sido o declínio dos preços das passagens. O preço da passagem aérea entre Tóquio e Osaka é hoje cerca de 10\% mais caro que o custo da viagem pelos Shinkansen (trem Bala).

Hoje em dia, uma importante prioridade para o espaço aéreo japonês é o aperfeiçoamento e a expansão dos transportes desse setor. A demanda aproxima-se de sua capacidade máxima tanto no novo aeroporto internacional de Tóquio, em Narita, 
na prefeitura de Chiba, como no aeroporto internacional de Kansai, que é o segundo mais importante aeroporto internacional do Japão, construído recentemente.

A partir do enfoque da atividade turística na transformação do paradigma da indústria moderna, infere-se que, para além da manipulação de macroestruturas sociais, políticas e econômicas, as relações humanas e a realidade coletiva reafirmam a importância da linguagem verbal, da qual depende o nosso acesso ao mundo, às coisas e às pessoas.

Por isso, não interessa aqui uma retrospectiva da história do Japão, no que tange ao desenvolvimento do turismo nacional e internacional, senão articular o que foi exposto anteriormente na introdução sobre um complexo de contribuições que, na convergência da estrutura técnica e dos recursos humanos, possibilitaram a aproximação de mundos distintos e pessoas muito distantes.

Em linhas gerais, aqui o desempenho do setor de serviços na economia japonesa seria o responsável por essa análise das relações turismo e consumismo e turismo e transporte. Relações essas que, em última instância, respondem pelo movimento de pessoas ao redor do mundo.

Desse modo, a concepção anterior do turismo, de incentivo à indústria e do comércio de bens, cede a posição destacada por tanto tempo usufruída a uma linha que remonta a interesses e valores distintos do instrumental técnico da atividade econômica.

Este enfoque do desenvolvimento da infra-estrutura turística do Japão, nas décadas de 1970, 1980 e 1990, representa uma tentativa de acompanhar essa conversão do turismo industrial para o turismo de massa na sociedade japonesa e na passagem do comércio de bens para o fortalecimento da indústria de serviços na sociedade global.

Abstraindo o embate ideológico e privilegiando as mudanças decorrentes da transformação do capitalismo (quem sabe, do neocapitalismo) em escala mundial, o fluxo e a diminuição de distâncias entre as pessoas, produto da evolução material, puseram povos e culturas sob problemas insolúveis. 
Enfim, é nesse plano ou nessa ordem de sentido que, a política dos sistemas de transportes e comunicação, a experiência japonesa converge as causas e os efeitos dos pólos emissores de fluxos, dos espaços de deslocamentos e dos núcleos receptores de turistas, cujo evento reforça o paralelo das habilidades dos recursos humanos com os avanços da técnica e com a melhoria do setor de serviços.

A seguir, será abordada a relação entre guias-intérpretes e visitantes estrangeiros que atinge o interior da cultura de turismo consolidada no Japão.

\subsection{O Problema da Linguagem}

Não parece difícil reconhecer que, por trás do progresso esperado em decorrência da atividade turística, o intercâmbio e a atração de estrangeiros refletem problemas nem sempre previsíveis na relação entre anfitriões e visitantes. Nos limites de tempo e espaço dispensados a este trabalho, o problema da linguagem e o lugar da fala na mediação do fenômeno turístico figuram como questões não menos preocupantes para o desenvolvimento do turismo sustentável.

Tomando por base os objetivos da política de turismo estratégico (TABELA 2), de S. Wanhill (1997), não é difícil concordar que o setor de turismo se apresenta como uma alternativa para o desenvolvimento econômico futuro. No entanto, conforme o intercâmbio e o impacto social e cultural decorrentes do turismo, esse desenvolvimento não é simples, exige planejamento visando a maximização dos impactos positivos que a atividade pode gerar e a minimização dos negativos.

Em síntese, conforme os dados e as considerações expostas até agora, de uma forma ou de outra, o privilégio da indústria do turismo em resposta às críticas externas ao modelo japonês ratifica o pressuposto de que, passando pela combinação de fatores sociais, políticos, econômicos, ambientais e culturais, a atividade turística poderia ser tomada como medida compensatória contra os desajustes de outros setores da economia. 
Por outro extremo, no que tange à aproximação de mundos distantes e pessoas muito diferentes, a preocupação com a linguagem figura como ponto determinante para o fato das relações internacionais e do turismo. Sem privilegiar necessariamente os acontecimentos relativos ao turismo industrial no Japão, na década de 1960, trata-se aqui de um tema tão importante quanto a modernização e disseminação das comunicações eletrônicas e o alargamento e barateamento das ofertas de transporte.

A par da produção de bens e serviços, na zona turística pode-se pensar em medidas elementares que contribuam para a satisfação das necessidades de consumo. Na mediação entre a oferta e demanda turística, a tentativa de garantir a permanência do turista guarda certa relação com a preocupação pela conveniência do visitante das indústrias e das empresas do Japão.

Receptividade e hospitalidade aparecem nesse contexto como sínteses de um conjunto de comportamentos, de políticas e de técnicas levadas a cabo para realizar a aproximação do turista com o local visitado e, nesse sentido, estender o turismo para uma relação humana de qualidade, a fim de satisfazer curiosidade, necessidades, gostos e aspirações, de desenvolver um clima de reencontros e de troca, de estimular o conhecimento, a tolerância e a compreensão entre anfitriões e visitantes.

\section{TABELA 2.1 - Dicas de Turismo no Japão}

\section{Intérpretes e Guias}

Há cerca de 1550 intérpretes licenciados no Japão para os idiomas português, inglês, espanhol, etc. Dispõe de mais de 800 guias turísticos profissionais que falam espanhol ou português, no Japão. O idioma nacional é o japonês, mas o inglês é falado em todo o Japão, particularmente nas principais cidades e nos centros históricos. Anúncios públicos sobre transportes, com opor exemplo nos trensbala que cruzam o país, são normalmente feitos em japonês e inglês e as placas indicativas geralmente incluem os caracteres romanos ou explicações em inglês. Vale a pena observar que muitos japoneses não têm confiança na sua habilidade de falar o inglês e mostram-se reservados ao primeiro contato. Lembre-se, portanto, de falar o inglês devagar e claramente e dar um sorriso para encorajá-lo ao diálogo. Tente aproximar-se primeiro de estudantes ou de executivos porque provavelmente eles entendem melhor o inglês oral. Levar um bloquinho e uma caneta é uma ótima idéia pois os japoneses sentem-se mais à vontade em lidar com o inglês escrito. $O$ fato mais importante que se deve lembrar é que os japoneses são muito acolhedores e mesmo aqueles que pouco ou nada entendem de inglês, com certeza, correrão para prestar-lhe auxílio. Independente do fato de que é possível viajar pelo Japão mesmo sem falar a língua, sempre é útil saber algumas palavras e frases em japonês. É bom saber falar um simples "obrigado" ou "olá" na língua deles e os japoneses apreciarão os seus esforços.

Fonte: Organização Nacional do Turismo Japonês (ONTJ). 
Essas sugestões remontam à preocupação com a hospitalidade e com a permanência do turista no Japão. A partir da era pós-industrial muitos eventos antes voltados para preocupações alheias ou externas aos recursos humanos, passaram a exigir o apoio de ferramentas até então dispensáveis, precisamente no que se refere à relação entre linguagem e comunicação.

Agora vive-se em um tempo marcado pelo intercâmbio de fatos, signos e imagens. Aqui a alta tecnologia figura como um dos aspectos, dentre outros, da competição contemporânea, ela não dispensaria nem tomaria o lugar reservado aos jogos de linguagem, estes construídos a partir inclusive do turismo.

Nesse contexto de grandes transformações, apesar do fator econômico que impera sobre as relações sociais, depende-se de fato da complementaridade dos recursos humanos, que permitem a combinação de fatores e o intercâmbio sóciocultural.

Para enfatizar as considerações do contraste entre o passado e o presente, entre a industrialização e a indústria dos serviços, evoca-se a filosofia prática cuja lógica tem suas próprias leis e que marginaliza o mundo real, ou dele absorve apenas aquilo que se ajusta à racionalidade econômica e ao imediatismo.

Contudo, em razão do caráter dinâmico da atividade turística, somado à necessidade de promoção do desenvolvimento social e econômico, hoje surgem novas iniciativas visando explorar cada vez mais as potencialidades do turismo, dentre as quais vem despontando, de forma promissora e com incontestável benefício para o setor, a qualificação de profissionais que atuam diretamente com o visitante estrangeiro.

Sabe-se que, na diversidade de segmentos que hoje compreendem a atividade turística, a exigência por mão-de-obra especializada surge como a conseqüência natural desse setor. Por sua vez, turistas oriundos de roteiros internacionais ou mesmo do turismo doméstico recorrem cada vez mais a uma estrutura confiável de lazer, cultura, negócios e entretenimento.

Assim, além da preocupação com o consumo de bens e serviços de segmentos tradicionais, visto como um todo, o turismo passa a depender do estreitamento e da 
garantia dos laços do visitante com o espaço previamente escolhido para essa atividade.

Nessa perspectiva, as iniciativas públicas e privadas envolvendo governos e sociedade civil, parecem insuficientes no sentido de abranger as potencialidades da atividade turística, bem como seus efeitos. Nesse particular, e retomando uma passagem anterior deste trabalho, os efeitos negativos mencionados antes apontam para esse vazio entre a promoção e o planejamento do turismo.

Tomando por base o privilégio de algumas variáveis em detrimento de outras que tornam possível a atividade turística, reflete-se aqui, de forma breve, sobre a qualificação de profissionais que atuam diretamente com os visitantes turistas na experiência turística japonesa, o que determina o estreitamento dos contatos, das relações e das mediações turísticas naquele país.

Aqui com o título O problema da linguagem, não se pretende outra coisa senão discorrer sobre medidas que, sem deixar de lado o fator econômico do turismo, estão relacionadas com a hospitalidade e com o acesso de estrangeiros aos espaços turísticos.

Nesta subseção, pretende-se mostrar como o crescimento e a renovação dos segmentos turísticos dependem da qualificação de guias-intérpretes, mediadores entre a demanda e a oferta do turismo.

Contrastando com o desenvolvimento social local decorrente da atividade turística, uma teoria econômica e um empirismo lógico, combinados com objetivos imediatistas que reduzem o turismo às ambições do sistema capitalista, prolongam de certa forma o positivismo que se instala na raiz mesma das práticas produtivas modernas. Associado a isso, direta ou indiretamente, o padrão globalizado da hospitalidade imposta pela sociedade global implica num quadro de insatisfações e de perigo. É sabido que o desenvolvimento estritamente econômico está por trás da concentração de renda dos países e dos índices sociais nacionais negativos. Por isso, é público que, por si só, o turismo não pode contribuir com o desenvolvimento dos destinos turísticos. 
Agora, constata-se um perigo que parece implícito na emergência de uma nova economia baseada na revolução atual, que proporciona sistemas de negócios ágeis e enxutos (NÓBREGA, 2000). Em outras palavras, pode-se dizer que, no horizonte da teoria e da racionalidade econômica que cria determinismos, a indústria de serviços que engloba o presente tema pode representar simplesmente um alargamento do reducionismo econômico ao universo dos fenômenos sociais, lingüísticos e culturais.

Ao reconhecerem o problema da linguagem, na mediação entre a procura e a oferta decorrentes do turismo, os japoneses se apresentam como aqueles que estreitam os laços dos recursos humanos com a modernidade, esta, refletida na tecnologia de última geração. A promoção de guias-intérpretes para visitantes e turistas retrata como isso ocorre, para a compreensão de uma cultura em que o desenvolvimento da linguagem verbal e a alta tecnologia não são mutuamente excludentes.

Ao analisar o fenômeno do turismo, entra-se em contato com duas questões importantes: o interesse dos turistas e os atrativos do local que recebe os turistas. $O$ turista procura condições que ocupem seu tempo livre e que atendam a seus interesses. Os receptores visam atrair os turistas por meio daquilo que já possuem ou daquilo que têm conseguido através do trabalho e de oportunidades de investimento. $O$ relacionamento entre essa duas partes produz resultados que levam o local visitado ao desenvolvimento econômico. Na medida em que certa localidade se organiza e dinamiza o setor turístico, é que o turismo começa a produzir seus resultados através do consumo de bens e serviços.

Para a mediação entre o local visitado e o acesso ao atrativo turístico, no Japão, desde 1949, conforme a revista Turism in Japan a qual foi utilizada neste trabalho, uma pessoa que deseja trabalhar como um guia turístico para visitas estrangeiras tem que passar por exame nacional, a fim de obter uma licença emitida por órgão competente da administração pública onde ele ou ela vivem.

Após emenda à lei de serviços de guia-intérprete, em 1983, o Ministério dos Transportes japonês confia à Organização Turística Nacional do Japão (JNTO) a tarefa 
de administrar o exame nacional para guia-intérpretes. Em 1990, o número de candidatos que fizeram o exame era de 5562, dos quais 633 tiveram sucesso.

Deixando de lado perguntas ou conseqüências demasiado importantes da noção de significado, entre história e desenvolvimento econômico do Japão, destaca-se de alguma forma o paralelo entre a competência comunicativa e a abertura do país como um destino atraente para o turismo.

A tabela 2.4 mostra o número de candidatos selecionados para guias-intérpretes por língua, nas décadas de 1970, 1980 e 1990, o que de fato reflete a diversidade e o fluxo de visitantes estrangeiros que tomam o Japão por destino.

TABELA 2.4 - Número de Candidatos Selecionados para Guias-intérpretes por Língua

Língua

Inglês Francês Espanhol Alemão Chinês Italiano Português Russo Coreano Década

\begin{tabular}{cccccccccc}
\hline 1970 & 285 & 16 & 20 & 20 & 10 & 3 & 1 & 5 & - \\
& $(108)$ & $(6)$ & $(11)$ & $(7)$ & $(1)$ & $(1)$ & & $(1)$ & \\
1980 & 4286 & 129 & 208 & 178 & 106 & 27 & 21 & 76 & - \\
& $(1670)$ & $(113)$ & $(94)$ & $(108)$ & $(27)$ & $(16)$ & $(8)$ & $(52)$ & \\
1990 & 5259 & 251 & 274 & 243 & 189 & 39 & 28 & 103 & 61 \\
& $(3015)$ & $(275)$ & $(238)$ & $(246)$ & $(158)$ & $(47)$ & $(21)$ & $(83)$ & $(28)$ \\
\hline Total & 9830 & 396 & 502 & 502 & 305 & 69 & 50 & 184 & 61 \\
& $(4793)$ & $(394)$ & $(502)$ & $(361)$ & $(186$ & $(64)$ & $(29)$ & $(136)$ & $(28)$ \\
\hline
\end{tabular}

Obs.: Entre parênteses está a classificação feminina.

Fonte: Tourism in Japan, edições de 1969-70, 1980 e 1991.

O trabalho do guia-intérprete é guiar visitas estrangeiras a vários locais no Japão, comunicando a cultura e a tradição da sociedade japonesa em idioma estrangeiro. Há uma diferença grande entre o intérprete e o guia-intérprete, ou seja, 
entre interpretar palavras faladas fielmente e achar palavras do seu próprio vocabulário para permitir o acesso do turista ao que lhe é realmente estranho.

Segundo dados da Japan National Tourist Organization ${ }^{4}$ (JNTO), o trabalho de um guia-intérprete se divide em guiar grupos, na administração de itinerários e excursões, confirmar reservas para alojamentos, como também fazer compras. Há, nesse contexto, muitos acontecimentos inesperados nos deslocamentos turísticos: engarrafamento, crianças perdidas, propriedade perdida, doença etc.

Para ser um bom guia-intérprete em qualquer ocasião, é necessário apresentar qualidades particulares para esse trabalho. O negócio de guia-intérprete no Japão demanda sem dúvida muito esforço, contudo, é muito solicitado. Os guias têm oportunidade de visitar vários lugares e de conhecer pessoas do mundo inteiro.

Se os turistas estrangeiros vão para casa com impressões boas sobre o Japão, acreditam os responsáveis pelas políticas voltadas para o visitante turista, depende da competência dos guia-intérpretes. Isso é a razão por que um guia-intérprete é considerado como um diplomata privado.

No Japão, a lei que regula o serviço de Guia-intérprete entrou em vigor em 1949, para regular o negócio de guia-intérprete. Ela atribui ao guia-intérprete a função de assistir a visitas estrangeiras, reconhece a importância das viagens de estrangeiros para o Japão e afirma a necessidade de proteção para os guia-intérpretes.

A lei do serviço de Guia-intérprete estipula que o trabalho desses profissionais é escoltar os estrangeiros e lhes prestar serviços relativos à viagem, com o uso de um idioma estrangeiro. Pelo menos no Japão, o que significa isso? Significa que, se alguém guiar os estrangeiros em um idioma estrangeiro sem a licença de guia, é ilegal. Assim para a qualificação de guia-intérprete, é necessário passar no exame elaborado pelo Ministério dos Transportes e adquirir licença emitida pelo governo do distrito local.

\footnotetext{
${ }^{4}$ Estabelecida em 1964, a Organização Turística Nacional do Japão (JNTO) se envolveu desde então para promover o fluxo turístico e as atividades de promoção do turismo no Japão. Esses compromissos levaram a cabo Centros Turísticos operacionais no Japão, para visitas estrangeiras, consolidando instalações de recepção para essas visitas, bem como promovendo convenções internacionais e feiras de comércio.
} 
Tomando por hipótese o acesso à realidade, na mediação entre guias-intérpretes e os diversos falantes estrangeiros, deve-se e pode-se retratar aqui o problema lingüístico, de quando dois falantes não compartilham o mesmo vocabulário.

$\mathrm{Na}$ contemporaneidade, a cultura dos negócios ágeis e enxutos parece transformar a noção de significado, torná-la flexível e dinâmica. O que representa talvez um recurso para por as pessoas em contato com as coisas, com os seres e com o mundo que as rodeiam, sem as fecharem em redes lingüísticas tão radicais que acabam impedindo o acesso à realidade.

De certa forma, a despeito da racionalidade econômica, quando se recusa a existência de convenções ou de significados comuns como elementos imprescindíveis e constitutivos da comunicação, não se nega, naturalmente, a existência da linguagem natural compartilhada por uma determinada comunidade de falantes.

Realmente, tem sentido dizer que um grupo de pessoas fala francês, alemão ou italiano. Com isso se quer dizer, simplesmente, que todas elas tendem por natureza e aprendizagem, a empregar as palavras, mais ou menos, da mesma maneira. Isso é o mesmo que dizer que uma determinada comunidade compartilha os mesmos costumes na rua ou usa os mesmos utensílios para comer.

Por outro extremo, na interação entre verbalização e acesso aos atrativos turísticos, a conversão de significados transportados pelo idioma de um determinado povo para noções flexíveis e dinâmicas aponta para dois pontos que não se confundem nem se excluem: um primeiro ponto teórico, em função do qual a fidelidade à crítica dos valores tradicionais assume um caráter pragmático; e um segundo ponto prático, em função do qual a competição contemporânea assume um caráter pragmático subordinando a linguagem à teoria econômica.

Nesse entrecruzamento da lingüística com o turismo, pelo qual os guiasintérpretes japoneses se ocupam da adaptação do idioma para os visitantes turistas, o estímulo para a interação de costumes e valores da sociedade japonesa entre visitantes e anfitriões, mediante a comunicação verbal, desemboca na questão da competência comunicativa, noção complementar à competência lingüística e, neste caso, suplementar à hospitalidade turística. 
Para compreender as preferências de um visitante turista necessita-se dominar certo conhecimento geral das coisas, de modo que parece impossível que se possa identificar um determinado e específico saber da linguagem que não esteja já entrelaçado do conhecimento da realidade. Isto deve aumentar a responsabilidade dos que pretendem relativizar a noção de significado relativa à linguagem.

A fronteira entre competência comunicativa e o saber comum do mundo e das coisas esconde um grande desafio no confronto da lingüística aplicada com a racionalidade econômica imperativa. Nesse contexto, a relativização da noção de significado, tendo em vista a superação de redes lingüísticas que acabam fechando o acesso à realidade, preserva uma situação análoga à encontrada no privilégio da infraestrutura turística.

Aqui o ponto de inflexão entre a atividade turística e a racionalidade econômica é a modernidade e o progresso reduzidos a medidas que eliminam ou menosprezam o acréscimo de outros recursos também essenciais para a indústria do turismo, a exemplo da introdução de guias-intérpretes na política turística japonesa. 


\section{CAPÍTULO 4 - ANÁLISE DOS DADOS}

\subsection{Introdução}

Este capítulo tem por finalidade apresentar uma análise do crescimento e da renovação de atividades produtivas impulsionadas pela pós-industrialização, a partir de dados e fatos que compreendem o turismo japonês praticado dentro da produção e da prestação de serviços disponíveis no mundo e das regras do mercado global.

Confrontando as transformações da sociedade global com o atual processo de viagens e turismo no centro das projeções econômicas mundiais, foi possível inferir que a cultura turística no Japão se estrutura entre aspectos culturais importantes da terra do sol nascente e as viagens turísticas emissivas. Neste último caso, esse dado compreende o número elevado de japoneses que participa do fluxo internacional de pessoas pelo mundo.

Concentrados nos dados apresentados pela Organização Nacional do Turismo Japonês (ONTJ), foi traçado um perfil da atividade turística japonesa. A primeira preocupação que surgiu, na análise dos dados, foi a de classificar o turismo por categorias, seguindo o tipo de participantes: o turismo emissivo e o turismo receptivo. Enquanto alguns países, segundo é sabido, preparam-se para atrair visitantes turistas, outros promovem viagens emissivas.

No caso do Japão, foi possível observar como o turismo incorpora aquela combinação de fatores que, na sociedade capitalista contemporânea, estão alinhadas à convivência de diferentes sistemas, concepções, tendências e regimes.

\subsection{Crises e Mudanças Intensas e Abrangentes}

As crises financeiras internacionais, aparentemente extrínsecas ao atual processo de viagens e do turismo, estão intimamente relacionadas com as mudanças 
globais intensas e abrangentes. Para confirmar isso, basta observar interiormente causas e efeitos de crises recentes.

Observa-se, sem muito esforço, ante a possibilidade de o trabalhador poder dispensar menos tempo ao trabalho e poder desfrutar mais de tempo livre, que o observador externo perceberá que esse fato importa certa melhoria nas condições de vida das pessoas (ou de um determinado contingente da população mundial).

Contudo, relacionando a experiência de redução da jornada de trabalho com a possibilidade das viagens turísticas, percebe-se que os trabalhadores com maior tempo livre não são necessariamente a clientela em potencial do setor de turismo. A respeito disso, em muitos casos a diminuição da permanência no trabalho evolui para o desemprego, que é um dos efeitos marcantes de crises estruturais recentes e que atingem a sociedade com um todo.

Em linhas gerais, a melhoria das condições de vida e a alteração operada nas relações trabalhistas confrontam diretamente com as expectativas do progresso, isto em razão do terror que tem sido produzido com o desemprego ou com a reestruturação da sociedade do trabalho em contraposição à indústria dos serviços e do emprego temporário.

Baseado nesse cenário, torna-se importante considerar as férias longas e o tempo "livre" do trabalhador como uma reestruturação da economia e das condições de crescimento de algumas sociedades. No Japão em particular, o turismo de massa ainda representa uma novidade contrastante com a ideologia do trabalho representativa da sociedade japonesa.

Nesse contexto, crises estruturais recentes impõem o ajuste de contas, fazendo que aquilo que antes coincidia com as oportunidades de ócio, lazer e turismo na vida de algumas pessoas seja enquadrado como aviso prévio ou ação indenizatória por bens, serviços e contratos rescindidos.

A revolução científica e tecnológica propulsora do surgimento da sociedade pósindustrial é de fato um dos principais fatores associados ao crescimento do turismo a partir dos anos 50. Para saber como e por que isso ocorre, é preciso recuperar o tema 
das facilidades e das novas técnicas postas em práticas com o avanço tecnológico, com a revolução da informática e com modernos aparelhos eletrônicos.

Baseado na análise do modelo da sociedade pós-industrial importa esclarecer aqui o uso da expressão transição da economia de bens para a indústria do turismo no mundo, sob a ótica da crise financeira e das mudanças estruturais globais contemporâneas legitimadas por esta última ${ }^{5}$.

Sabe-se que o suporte tecnológico, as mudanças econômicas, a valorização que as pessoas começaram a dispensar às atividades ligadas ao lazer, às artes, à culturas e os contatos internacionais estão transformando a lenta evolução que caracterizou as sociedades do passado.

O turismo é considerado um dos setores da atividade econômica, que está mais exposto às alterações produzidas na sociedade e aquele que melhor as reflete. A própria dimensão e importância que a atividade turística alcançou é resultante das mudanças operadas na sociedade e da evolução do gênero de vida que elas produziram.

Em síntese, cada período de mudança da sociedade implica na imposição de conseqüências de uma região para outra do planeta ou de um setor para outro da economia. Transformações na sociedade, na política e na economia que obrigam que variáveis distintas e agentes sociais diversos tenham de acompanhar tendências e mudanças operadas na sociedade global, quer no domínio da oferta, quer no da procura.

Por outro extremo, as transformações econômicas, sociais e políticas da atualidade levam a considerar que a chave dos problemas da nossa época já não residem tanto nas questões econômicas, mas também na renovação dos valores sociais e culturais. O que obriga a dar maior atenção e a realçar os fatores e elementos

\footnotetext{
${ }^{5}$ Os efeitos da crise financeira da Ásia, de 1997, com os quais estamos em contato ou pelo quais somos indiretamente afetados, não representam um desastre exclusivamente asiático. O que ocorre com as economias dos países envolvidos nessa crise, apesar do processo de desenvolvimento e aperfeiçoamento técnico, significa, em linhas gerais, retrocesso econômico, ou seja, um quadro de crise na economia asiática que tende a gerar problemas sociais e políticos mundiais.
} 
não materiais da vida: os valores humanos, o fortalecimento da cultura e da preservação do patrimônio natural.

Para enfatizar o efeito dominó relativo às mudanças que se arrastam por todas as atividades com as quais estão relacionadas o próprio turismo, não custa evocar aqui a crise financeira ocorrida na Ásia, 1997/1998. Após isso, será retomada a questão da outra causa dos problemas da nossa época

Com a crise asiática de 1997, todos ficaram sabendo que o internacionalismo e o regionalismo desafiam, externamente, a soberania dos Estados e o futuro de cada um, quer dos protagonistas, quer dos países subdesenvolvidos excluídos no processo econômico global.

A crise asiática foi disparada por um processo de fuga de capital e deflação de ativos financeiros em certo conjunto de economias daquela região. A perplexidade diante da crise foi proporcional ao fato de que, até bem pouco antes, a região do Pacífico Asiático se configurava como fronteira de crescimento econômico aparentemente inexaurível.

Apesar de tudo e das projeções catastróficas, o turismo sobreviveu mesmo enfrentando grandes desafios, tal como a perda da confiança sobre o futuro dessa atividade na região da Ásia-Pacífico. No Japão, segundo Kenneth Chamberlain (2003), as viagens ao exterior caíram durante catorze meses consecutivos. As viagens de negócios entre as capitais asiáticas caíram por volta de $30 \%$. O enfoque da indústria era a sobrevivência. As necessidades de curto prazo criaram um ambiente de corte de taxas. A renda foi sacrificada em favor do fluxo de caixa:

Chamberlain sintetiza que, após a reviravolta provocada por essa crise e com o retorno à normalidade na região, a economia está em processo de recuperação:

[...] As companhias fortes sobreviveram e as fracas desapareceram. As mais fortes trabalham num contexto de baixo custo para poderem se reagrupar e expandir, e a confiança está voltando. Uma preocupação é que a recuperação esteja acontecendo de forma muito rápida e o crescimento renovado possa levar aos problemas estruturais subjacentes que contribuíram para a crise, que já foi esquecida na corrida por novos negócios e ganho de curto prazo. (CHAMBERLAIN, 2003: 140) 
No tocante ao tema das viagens turísticas no Japão, o referido autor escreveu o seguinte:

O Japão começou como um mercado de viagens moderno em 1964, quando o controle cambial foi liberado, e é, agora, um mercado relativamente maduro. Viajar está dentro das condições da maioria das pessoas. O Guia de turismo com a bandeira praticamente, desapareceu; as pessoas estão viajando com seus familiares ou amigos. O crescimento está nas viagens independentes, com itinerários personalizados, e as viagens com interesses especiais estão muito bem estabelecidas. Os itinerários não estão tão lotados e até mesmo fazer compras está em um nível mais baixo na escala de preferências. Essas tendências continuarão. (Op. cit., p. 143)

Devido a desvalorização de moedas estrangeiras em relação ao dólar, na qual mergulharam as moedas nacionais de muitos países asiáticos, todo processo de desenvolvimento e aperfeiçoamento de um modelo econômico aparentemente inexaurível caiu por terra. Contudo, no tocante ao que seria o objetivo desta subseção, uma das lições da crise asiática implicou na conversão das empresas demasiado hierarquizadas, que tiveram de romper com o passado.

Por sua vez, a evolução técnica e científica dos próprios tigres asiáticos, centros de uma crise global, impôs que os encaminhamentos mais imediatos se fizessem acompanhar por soluções de alcance mais estrutural.

Assim com base nas conseqüências desencadeadas pela crise, a evolução da demanda turística da Ásia como um todo seria acompanhada com a mudança na estrutura industrial das economias voltadas para a exportação de tecnologias de ponta. Intensas e abrangentes, tratam-se de predicados pelos quais é possível retratar as mudanças estruturais e complementares de um mundo em transformação.

Se, por um lado, a modernização e disseminação das comunicações e o alargamento e barateamento das ofertas de transporte podem ser percebidos como produto da revolução científica e tecnológica da sociedade pós-industrial incorporada à demanda turística, por outro, o turismo pode ser visto como um dos vários fatores transformadores do sistema capitalista. 
A viagem turística atual é decorrência da sociedade industrial que provocou uma concentração de pessoas em cidades, de tal sorte que a fuga desse meio ambiente tornouse até mesmo uma questão de sobrevivência. A viagem turística passou a ser para o homem urbano atual um produto de primeira necessidade (CASTELLI, 2001:16)

Tentando combinar os limites deste trabalho com as mudanças impostas pela necessidade do desenvolvimento sustentável que busca responder à ameaça e à instabilidade provocadas pela especulação financeira e pela globalização dos mercados, não parece impossível nem inoportuno situar o crescimento do turismo numa certa redução da economia de bens e crescimento da indústria de serviços.

A despeito de uma nova configuração das estruturas mundiais, na qual o turismo representa uma das forças transformadoras do mundo pós-industrial, não se pode perder de vista a importação de novas preocupações e posturas no intercurso dessas conexões ou mesmo do crescimento da indústria dos serviços.

O suposto de que a chave dos problemas da nossa época já não residem tanto nas questões econômicas, deve de alguma forma inspirar-nos a esse respeito.

Da mesma forma que o turismo industrial no Japão na década de 1960 implicou na compilação de um arquivo de empresas e fábricas nacionais em japonês, para as conveniências de visitas estrangeiras, a maior atenção e o destaque para fatores e elementos não materiais da vida (valores humanos, fortalecimento da cultura e preservação do patrimônio natural) levam a pensar no tema das competências transversais de comunicação.

Supondo que as transformações na sociedade, na política e na economia tenham de acompanhar, com particular atenção, as tendências e mudanças operadas na sociedade global, quer no domínio da oferta, quer no da procura, o desenvolvimento da competência comunicativa em contextos elementares e específicos do âmbito turístico figura aqui como uma transição entre problemas decorrentes do turismo e da atividade econômica propriamente dita.

Fora disso, como poderia ser pensado o salto de um sistema para outro, de uma sociedade para outra, do turismo industrial para o turismo de massa, da necessidade de 
compensar setores da economia para a preocupação com o desenvolvimento sustentável, senão no desencadeamento de competências transversais?

\subsection{Mediação e adequação da fala}

Abstraindo críticas e comentários da lingüística aplicada ao turismo, sabe-se que o conceito de competência comunicativa é bastante amplo para incluir não só as regras que presidem à formação das sentenças, mas também as normas sociais e culturais que definem a adequação da fala.

Por isso, no tocante às medidas de sustentabilidade ou conscientização e controle da atividade econômica, foi enfatizado aqui, o tema da comunicação entre as pessoas que viajam ou, até mesmo, o contato direto com a natureza e a cultura do lugar visitado, cujo aspecto aparece refletido na preocupação dos guias-intérpretes japoneses, em mediar a comunicação entre o mundo local e o estrangeiro.

Resumindo a discussão anterior, desde a referência ao desemprego que marca a era pós-industrial, responsável por uma grande reestruturação da economia de bens fundamentada na sociedade do trabalho, passando ainda pela evolução dos sistemas de transporte e comunicação e pela simplificação dos conglomerados industriais e empresariais, o progresso técnico e a mudança na forma de perceber o mundo e as relações humanas apontam para as interfaces da economia e ambigüidades que orientam e ordenam a atividade turística.

Com isso, o presente autor pretendeu alcançar certo grau de independência para interagir num conjunto variado de situações. Ele discorreu sobre mecanismos linguístico-comunicativos, nomeadamente de reconhecimento e uso das principais estruturas léxico-sintáticas e sintático-semânticas da língua, que fazem a diferença para uma maior flexibilidade e capacidade para usar a língua em situações menos previsíveis.

Nessa perspectiva, a mediação do guia-intérprete japonês para estrangeiro, no êxito da comunicação, na ralação sociocultural do visitante com o espaço turístico, 
representa a própria competência comunicativa. Daí, a importância entre aprender e importar soluções para a questão do turismo e para uma cultura da hospitalidade a visitantes estrangeiros.

No entrecruzamento da competência comunicativa em contextos elementares e específicos com o vocabulário básico da área, o agente de turismo tem por responsabilidade interagir com o turista ou grupo de visitantes estrangeiros. Para tanto, esse agente, investido da função de mediar a relação entre a demanda e a oferta turística, precisará dominar manifestações sócio-culturais gerais, do local ao global, e poder, assim, aparelhar-se para a comunicação no contexto específico da atividade turística.

Sabe-se, entretanto, que existem infinitas oportunidades de mediação do diálogo entre anfitriões e turistas e que seria impossível prever todas essas situações.

A noção de competência comunicativa, segundo NAWA (1988), alargou o escopo do estudo das línguas em contato para além dos elementos puramente lingüísticos para incorporar, também, elementos culturais e comportamentais. Para o referido autor, o estudo da mudança de código, e aqui pensa-se na relação entre o visitante turista e o guia-intérprete, é, especialmente, interessante porque enfatiza o contraste sóciosimbólico existente no uso das duas línguas, quando os significados sociais, durante a interação, são manipulados pelos falantes.

[… Se levarmos em consideração o contexto mais amplo da mudança lingüística [e com isto lembramos da combinação de fatores sociais, econômicos, técnicos, culturais e políticos que integram o turismo], observamos que, através destas micro-situações, poderemos interferir e reconstituir todo um processo histórico-social que deve estar ocorrendo nesse determinado momento. (NAWA, 1988:69)

Para o presente autor, tomando como pretexto o vínculo da estrutura técnica com os recursos humanos aplicados ao turismo, no que tange ao atrativo turístico e à hospitalidade para visitantes estrangeiros, a transformação da atividade produtiva em proporções mundiais demanda um estudo específico da comunicação e das relações internacionais. Assim, lembrando da complementaridade e do aperfeiçoamento técnico dos transportes para o fluxo de pessoas no mundo, é preciso reconhecer todas as interfaces também do turismo. 
Em linhas gerais, neste trabalho está em discussão, de certa forma, o papel crescente da competência técnica e profissional, no desempenho do turismo e das relações internacionais em particular. Desde os trens de alta velocidade no Japão, que são por si só atrativos turísticos, aos guias-intérpretes japoneses, que acompanham os turistas em viagens e visitas a locais de interesse, o tema da competência relativa à produção e à prestação de serviços, nesse contexto, acompanha todo o desenrolar da relação entre anfitriões e visitantes estrangeiros.

Não há, pois, como confundir estrutura técnica e recursos humanos. Assim como não se pode confundir essas duas dimensões da atividade turística com a de evolução do setor de serviços. Suspendendo comentários e concentrando a atenção na realidade empírica, tanto a estrutura técnica quanto os recursos humanos são requisitos da promoção e do planejamento do turismo.

Estrutura técnica ou infra-estrutura é a contrapartida pública capaz de tornar os espaços turísticos como destinos atraentes do capital globalizado. Os recursos humanos ou a competência profissional dizem respeito às estratégias de marketing e condições de permanência do turista. Nesse último ponto, estão os guias-intérpretes, que acompanham os turistas em viagens e visitas.

No contexto das discussões motivadas pelo turismo, o observador externo percebe um conjunto de competências requisitado pela atividade turística: lingüística, sócio-lingüística, discursiva, estratégica e sócio-cultural, que depois formam a competência comunicativa.

Enfim, o turismo tem motivado inúmeras discussões, como a reestruturação de valores, costumes e hábitos da sociedade, assim como a interação entre o local e o global, de modo que alguns profissionais mais ousados já conseguem trabalhar um conjunto de variáveis que compreende essa atividade econômica de forma a não priorizar umas em relação a outras.

Se o conteúdo cultural é parte na interação entre anfitriões e visitantes, não se pode separar ou entender que, entre competência cultural e competência comunicativa, uma seja mais importante que a outra. Entretanto, é preciso que o agente de turismo 
seja competente, no sentido de que sua competência cultural lhe sirva para atuar junto aos indivíduos com quais ele entra em contato. 


\section{CONCLUSÃO}

A concepção atual do turismo tem vigência no século $X X$, quando se combinam uma série de fatores sociais, econômicos, técnicos, culturais e políticos. Trata-se de um pressuposto que de certa forma esteve presente aqui o tempo todo.

A perspectiva, ao longo deste trabalho, foi chamar a atenção para a relação e para o efeito multiplicador da atividade turística, como uma conseqüência positiva para o desenvolvimento local e/ou regional.

Também, devido à natureza e o alcance dessa discussão, ficará para uma futura oportunidade uma análise depurada do que, aqui, aparece apenas como ilustração de um problema maior, com o qual deve-se aprender e importar soluções para a questão do turismo e para uma cultura da hospitalidade a visitantes estrangeiros.

As análises econômicas, por si só, tendem a enfocar o turismo por uma perspectiva unilateral, ressaltando o lado positivo dos impactos econômicos do turismo, mesmo sabendo que há diversos impactos econômicos negativos como: sazonalidade, trabalhos temporários, falsa sensação de empregabilidade, etc.

Já o estudo dos impactos ambientais, sociais e culturais no desenvolvimento turístico tende a destacar a necessidade de uma cultura de turismo, sem abrir mão da responsabilidade com os impactos negativos e dos benefícios de potencialidades locais.

Por outro lado, é certo que, para que o Japão se constituísse um grande destino turístico mundial, foi necessário que ele consolidasse primeiro um turismo interno forte, de qualidade e competitividade, depois um turismo intra-regional significativo para, então, poder consagrar-se como um destino internacional.

Realmente parece inegável, no caso japonês, a existência de uma reforma interna entre os problemas trazidos pela modernização econômica da Era Meiji e a competição contemporânea.

No século $X X$, o lazer e o turismo tornaram-se atividades de massas, trazendo à tona, assim, muitas oportunidades de novos negócios, que atingiram um patamar de 
crescimento que fez com que, do ponto de vista econômico, passassem a ser considerados como indústrias que superam a economia de bens.

Atualmente, e isto curiosamente deve fundamentar o nascimento da era pósindustrial, a indústria e os serviços ligados ao lazer e ao turismo estão entre os campeões de crescimento, alinhando-se seguramente entre os mais promissores para o futuro.

Nesse contexto, sem reduzir o turismo ao significado econômico, é necessário buscar melhoria no quadro de concentração de renda ou dos indicadores sociais.

$\mathrm{Na}$ década de 70, com o aparecimento da Empresa Brasileira de Turismo EMBRATUR, surgiram no Brasil algumas novidades para a época, no tocante a esse tema, e, nesse sentido, a nova área do turismo e das viagens passou a competir com os velhos cursos de contabilidade, comércio, direito, medicina, dentre outros, abertos por todo o país.

O mundo contemporâneo, através do avanço técnico e lógico-científico, plantou a convivência de diferentes sistemas, tendências, regimes e concepções. De onde também emergem o crescimento e a renovação do particularismo sócio-cultural. Todas as manifestações dependem do respeito às histórias particulares de cada uma.

Nesse contexto, vale observar que, no que tange às relações sociais e ao convívio humano, cada sociedade confere especial preocupação à competição pela qual se passa hoje e que, na pluralidade de programas, projetos e utopias, é evidente o confronto entre a herança cultural e a mudança contemporânea.

Contudo, sobre as regiões que não tiveram muitas possibilidades de crescimento durante o domínio da sociedade do trabalho, assim como o Brasil, e a pretexto da competitividade e da mudança contemporânea, algumas análises parecem vislumbrar nisso a superação para dificuldade e limitações do desenvolvimento do turismo brasileiro. 


\section{REFERÊNCIA BIBLIOGRÁFICA}

CASTELLI, Geraldo. Turismo: atividade marcante. $4^{\mathrm{a}}$ ed. revisada e ampliada. Caxias do Sul: EDUCS, 2001.

CHAMBERLAIN, Kenneth. Ásia-Pacífico. In: Viagem e Hospitalidade no século XXI. A. Lockwood e S. Medlik (org.); tradução de Eliana Keeling e John Keeling Barueri, São Paulo: Manole, 2003.

CORDEIRO, Renato Caporali. Da riqueza das nações à ciência das riquezas. São Paulo: Loyola,1995.

CORIOLANO, Luzia Neide M. T. Do local ao global: O turismo litorâneo cearense. Campinas: Papirus, 1998.

DOLAN, Ronald E; WORDEN, Robert L. Japan: A country study. 5. ed. Washington: Libr Cong, 1992.

Empresa Brasileira de Turismo - EMBRATUR. Anuário Estatístico 2000. Vol. 27, 1-208: Brasília, 1998/1999.

GASTAL, Suzana. Turismo \& Cultura: por uma relação sem diletantismos. In: GASTAL, Suzana (Org.) Turismo: 9 propostas para um saber-fazer. Porto Alegre: EDIPUCRS, 2001 (Coleção Comunicação, 4).

GUTTMAN, Cynthia. Por uma ética do turismo. O Correio da UNESCO, p56, set./out., 1999.

JAPAN NATIONAL TOURIST ORGANIZATION. Revista Tourism in japan: 196970. Tokyo. 
Revista Tourism in japan:

1980. Tokyo.

Revista Tourism in

Japan: 1991. Tokyo.

NAISBITT, J. Megatendências Ásia: oito megatendências asiáticas que estão transformando o mundo. Rio de Janeiro: Campus, 1998.

NAKAMURA, Takafusa \& GRACE, Bernard R.G. Desenvolvimento econômico do Japão Moderno. Japão. Ministério dos Negócios Estrangeiros: Japão, 1985.

NÓBREGA, Maílson da. O Brasil em transformação. São Paulo: Editora Gente, 2000.

OLIVEIRA, Antônio Pereira. Turismo e Desenvolvimento: planejamento e organização. São Paulo: Atlas, 2000.

Organização Mundial do Turismo 2001: banco de dados. Disponível em: <http//www.world-tourism.org>. Acesso em: set. 2005.

ROBINSON, Mike. Por um turismo consensual. O Correio da UNESCO, pp.2223, set./out., 1999.

TODD, Graham. Viagem e turismo na atualidade. In: Turismo e hospitalidade no século XXI. A. Lockwood e S. Medlik (org.); tradução de Eliana Keeling e John Keeling. Barueri, São Paulo:Manole, 2003.

Tourism promotion as a pillar of Japan's policies. Disponível em: <http://www.mlit.go.jp>. Acesso em: 18 de set. 2005. 
WANHILL, S. Tourism Development and Sustainability. In: COOPER, C.P. Tourism Development: Environment and Community Issues. London: Wiley, 1997. 


\section{ANEXOS}

\section{TABELA 3.1 - OBJETIVOS DA POLÍTICA DE TURISMO ESTRATÉGICO}

\section{OBJETIVOS DA POLÍTICA DE TURISMO ESTRATÉGICO}

- Desenvolver um setor de turismo que seja, por todos os aspectos e em todos os níveis, de alta qualidade, embora não necessariamente de alto custo;

- Encorajar o uso do turismo para intercâmbio tanto cultural Quanto econômico;

- Distribuir os benefícios econômicos do turismo, diretos e indiretos, da forma mais ampla e para a maior parcela de comunidade anfitriã, quando viável;

- Preservar os recursos culturais e naturais como parte do desenvolvimento do turismo, facilitar isto por meio de desenhos de arquitetura e de paisagismo que reflitam as tradições locais;

- Atrair um largo segmento de turistas internacionais e domésticos, através de políticas e programas de desenvolvimento de locais e de instalações;

- Atrair turistas de alto nível de gastos;

- Aumentar o nível de emprego;

- Auxiliar regiões periféricas, pelo aumento de renda e emprego, deste modo reduzindo ou coibindo a emigração.

Fonte: Wanhill (1997) 


\section{Tourism in Japan: Status and Target}

\section{Imbalance between Inbound and Outbound Tourism}

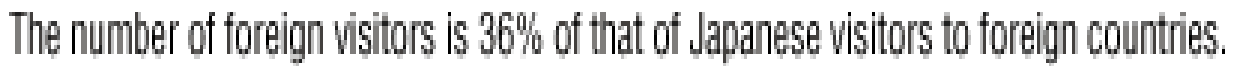
Negative tourișm balance of 23 billion dọllars (2.9 trillion yen) in 2002

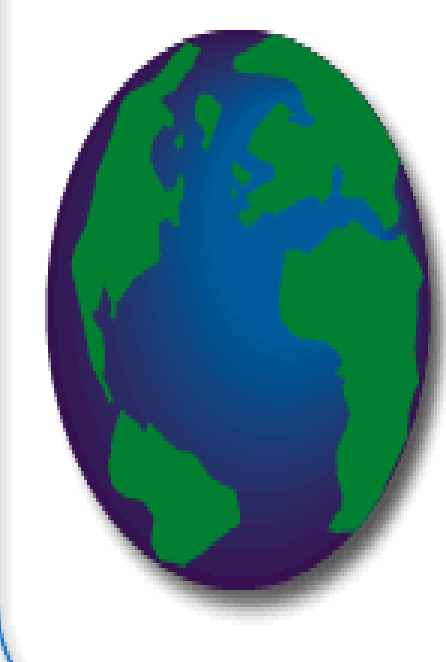

16.83 million overseas travelers

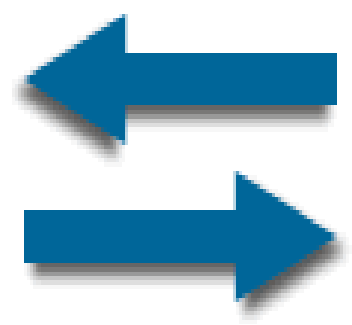

6.14 million foreign tourists
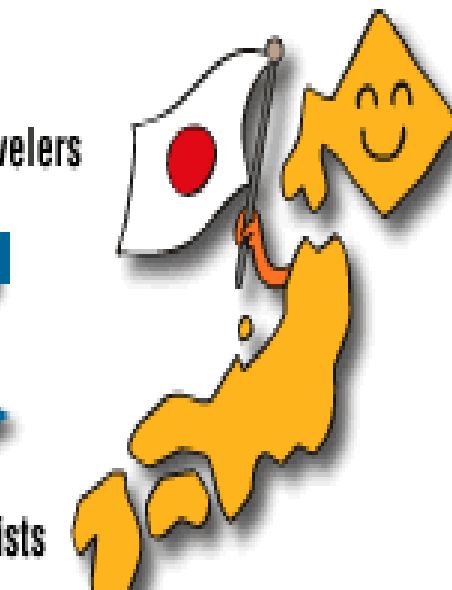

\section{Goal}

Attracting $\mathbf{1 0}$ million foreign tourists to visit Japan by the year 2010

(Policy speech by Prime Minister Koizumi in January 2003)

\section{Visit Japan Campaign started in April 2003.}

